\title{
CO source contribution analysis for California during ARCTAS-CARB
}

\author{
G. G. Pfister ${ }^{1}$, J. Avise ${ }^{2}$, C. Wiedinmyer ${ }^{1}$, D. P. Edwards ${ }^{1}$, L. K. Emmons ${ }^{1}$, G. D. Diskin ${ }^{3}$, J. Podolske ${ }^{4}$, and \\ A. Wisthaler ${ }^{5}$ \\ ${ }^{1}$ Atmospheric Chemistry Division, National Center for Atmospheric Research, Boulder, CO, USA \\ ${ }^{2}$ California Air Resources Board, Sacramento, CA, USA \\ ${ }^{3}$ Chemistry and Dynamics Branch, NASA Langley Research Center, Hampton, VA, USA \\ ${ }^{4}$ NASA Ames Research Center, Moffett Field, CA, USA \\ ${ }^{5}$ Institute for Ion Physics \& Applied Physics, University of Innsbruck, Innsbruck, Austria
}

Received: 17 November 2010 - Published in Atmos. Chem. Phys. Discuss.: 1 February 2011

Revised: 20 July 2011 - Accepted: 21 July 2011 - Published: 1 August 2011

\begin{abstract}
Air pollution is of concern in many parts of California and is impacted by both local emissions and also by pollution inflow from the North Pacific Ocean. In this study, we use the regional chemical transport model WRF-Chem V3.2 together with the global Model for OZone and Related Chemical Tracers to examine the CO budget over California. We include model $\mathrm{CO}$ tracers for different emission sources in the models, which allow estimation of the relative importance of local sources versus pollution inflow on the distribution of $\mathrm{CO}$ at the surface and in the free troposphere. The focus of our study is on the 15 June-15 July 2008 time period, which coincides with the aircraft deployment of the NASA Arctic Research of the Composition of the Troposphere from Aircraft and Satellites (ARCTAS) mission over California. Model simulations are evaluated using these aircraft observations as well as satellite retrievals and surface observations of $\mathrm{CO}$.

Evaluation results show that the model overall predicts the observed $\mathrm{CO}$ fields well, but points towards an underestimate of $\mathrm{CO}$ from the fires in Northern California, which had a strong influence during the study period, and towards a slight overestimate of $\mathrm{CO}$ from pollution inflow and local anthropogenic sources. The analysis of the CO budget over California reveals that inflow of $\mathrm{CO}$ explains on average $99 \pm 11 \mathrm{ppbV}$ of surface $\mathrm{CO}$ during the study period, compared to $61 \pm 95 \mathrm{ppbV}$ for local anthropogenic direct emissions of $\mathrm{CO}$ and $84 \pm 194 \mathrm{ppbV}$ for fires. In the free
\end{abstract}

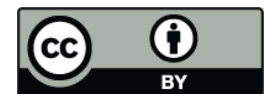

Correspondence to: G. G. Pfister (pfister@ucar.edu) troposphere, the average $\mathrm{CO}$ contributions are estimated as $96 \pm 7 \mathrm{ppbV}$ for $\mathrm{CO}$ inflow, $8 \pm 9 \mathrm{ppbV}$ for $\mathrm{CO}$ from local anthropogenic sources and $18 \pm 13 \mathrm{ppbV}$ for $\mathrm{CO}$ from fires. Accounting for the low bias in the $\mathrm{CO}$ fire emission inventory, the fire impact during the study period might have been up to a factor 4 higher than the given estimates.

\section{Introduction}

Carbon monoxide (CO) is the third most abundant carbonbased trace gas in the atmosphere, after carbon dioxide and methane and plays a key role in the production of tropospheric ozone and the budget of the hydroxyl radical. Its global distribution at the surface reflects the location of large emission sources but with a tropospheric lifetime on the order of weeks to months, $\mathrm{CO}$ is also a useful tracer for atmospheric pollution transport (Staudt et al., 2001; Liang et al., 2004; Yashiro et al., 2009).

The main sources of $\mathrm{CO}$ in the atmosphere include biomass burning and fossil fuel use, followed by oxidation of hydrocarbons and oxidation of methane. More than half of all $\mathrm{CO}$ emissions are considered to be man-made (Granier et al., 2000; Bey et al., 2001; Horowitz et al., 2003). The major global sink for tropospheric $\mathrm{CO}$ is reaction with the hydroxyl radical (Warneck, 2000). Average CO mixing ratios in the atmosphere are about $50-150 \mathrm{ppbV}$ in remote regions, $100-300 \mathrm{ppbV}$ in more rural regions and may reach up to several ppmV in urban areas where $\mathrm{CO}$ is hazardous to human health.

Published by Copernicus Publications on behalf of the European Geosciences Union. 
In this study we use the regional Weather and Research Forecasting Model with Chemistry (WRF-Chem V3.2) together with the global Model for OZone and related Chemical Tracers (MOZART-4) to examine CO contributions over California (CA) and assess the $\mathrm{CO}$ budget. The focus time period of our study is on the NASA Arctic Research of the Composition of the Troposphere from Aircraft and Satellites (ARCTAS) mission. As part of ARCTAS, the California Air Resources Board (CARB) sponsored flights over CA and the eastern North Pacific Ocean during the second half of June 2008. The objectives were to provide measurements that help to improve state emission inventories for greenhouse gases and aerosols, and to test and improve models of ozone and aerosol pollution (Jacob et al., 2010).

We use the aircraft measurements together with satellite and ground-based measurements of $\mathrm{CO}$ to evaluate the ability of WRF-Chem to capture the actual $\mathrm{CO}$ distribution and variability over $\mathrm{CA}$. The $\mathrm{CO}$ budget over $\mathrm{CA}$ is then estimated from the analysis of $\mathrm{CO}$ tracers that are included in the regional and the global model. CO tracers are artificial tracers that are added to a simulation and are produced or emitted from predefined sources and undergo the same transport, loss and chemical processes as the total simulated $\mathrm{CO}$. $\mathrm{CO}$ tracers are additive and the sum of all tagged sources (direct emissions and photochemical production) equals the total simulated $\mathrm{CO}$ mixing ratios.

Previous studies have applied the concept of "CO tracers" to keep track of the $\mathrm{CO}$ from different source terms in the analysis of the CO budget (e.g. Granier et al., 1999; Pfister et al., 2004, 2010; Duncan et al., 2007) and for improving emission estimates through inverse modeling techniques (e.g. Palmer et al., 2003; Petron et al., 2004; Heald et al., 2004; Arellano et al., 2004, 2006; Pfister et al., 2005; Kopazc et al., 2010). In a recent study, Huang et al. (2010) used the regional STEM tracer model with $\mathrm{CO}$ tracers in support of the analysis of the effects of transported background ozone on California during ARCTAS-CARB. In this study, we link the $\mathrm{CO}$ tracers in the regional model to the $\mathrm{CO}$ tracers in the global model through the lateral boundary conditions and follow the inflow of total $\mathrm{CO}$ as well as $\mathrm{CO}$ from individual source regions through the regional domain.

The outline of the manuscript is as follows. After an introduction of the modeling configuration in Sect. 2, we describe the set of observations used in the model evaluation and present results from the model evaluation in Sect. 3. Section 4 discusses the source contribution for surface $\mathrm{CO}$ and discusses pathways that bring pollution inflow down to the surface over CA. We further examine differences that arise between using a global versus a regional model in estimating the impacts of long-range pollution transport on local and regional surface air quality. In Sect. 5 we present a $\mathrm{CO}$ budget analysis for $\mathrm{CO}$ loadings integrated over the extent of the boundary layer and the free troposphere and Sect. 6 discusses a set of sensitivity simulations with altered anthropogenic and fire emissions. The study results are summarized in Sect. 7.

\section{Model simulations}

The regional chemical transport simulations were performed using the Weather Research and Forecasting model with chemistry (WRF-Chem Version 3.2) (Grell et al., 2005). The chemistry component of WRF-Chem is fully consistent with the meteorological component (WRF); both use the same transport scheme (mass and scalar preserving), the same grid (horizontal and vertical), and the same physics schemes for subgrid-scale transport. WRF-Chem includes online biogenic emissions and dry deposition and a photolysis scheme that is coupled with hydrometeors as well as aerosols. Our simulation uses the Bougeault-Lacarrere boundary layer scheme (Bougeault and Lacarrere, 1989) and the Noah land surface model (Ek et al., 2003).

The domain for our regional simulation is centered over CA with $159 \times 149$ grid cells and a spatial resolution of $12 \times 12 \mathrm{~km}^{2}$. We use 27 vertical levels between the surface and $50 \mathrm{hPa}$. Meteorological initial and boundary conditions are taken from the NCEP Eta North American Mesoscale (NAM) Analysis with analysis nudging for wind, temperature and humidity applied. Spatially and temporally (3hourly) varying chemical boundary conditions are provided by global model simulations from the Model for OZone and related Chemical Tracers (MOZART-4) (Emmons et al., 2010). The global model was run at a spatial resolution of $\sim 0.7^{\circ}$ by $0.7^{\circ}$ (T170) and the meteorological fields for driving MOZART-4 were taken from NCEP (National Centers for Environmental Prediction) - Global Forecasting System (GFS) Analysis. WRF-Chem and MOZART4 both employ the MOZART-4 gas-phase chemical scheme fully described in Emmons et al. (2010). The aerosols in the global MOZART-4 model include 12 bulk aerosol compounds. In WRF-Chem the MOZART-4 gas phase chemistry is linked to the bulk aerosol scheme GOCART (Goddard Chemistry Aerosol Radiation and Transport model; Chin et al., 2002). This configuration ("MOZCART") has recently been released in WRF-Chem V3.2.

Global and regional models are based on the same emission inventories where applicable. Anthropogenic emissions are based upon the US EPA's 2005 National Emissions Inventory (NEI) (version 3) (S. McKeen, personal communication, 2010) and over CA are replaced by an emission inventory provided by CARB (J. Avise, personal communication, 2010). NEI and CARB emissions are provided with hourly resolution separately for weekday, Saturday and Sunday and are mapped from the provided $4 \times 4 \mathrm{~km}^{2}$ resolution on to the WRF-Chem domain. 
The fire emissions inventory has been estimated using the Fire INventory from NCAR (FINN V1) (Wiedinmyer et al., 2006, 2011). FINN provides emissions on a per fire basis based on fire count information from the MODIS (Moderate Resolution Imaging Spectrometer) instrument. We apply a diurnal profile to the fire emissions following recommendations by the Western Regional Air Partnership (WRAP; Report to Project No. 178-6, July 2005), which peaks in the local afternoon and emits very little during nighttime. Fire emissions in MOZART-4 are released at the lowest model level, while in WRF-Chem the online plume rise module (Freitas et al., 2007) is applied to distribute the fire emissions vertically. Biogenic emissions are calculated online following the Model of Emissions of Gases and Aerosols from Nature (MEGAN) (Guenther et al., 2006). Emissions in the global MOZART-4 model for the rest of the globe are based on the ARCTAS emission inventory developed by D. Streets and Q. Zhang (http://www.cgrer.uiowa.edu/arctas/emission. html).

The CO fire emissions over the regional domain for the time period 15 June-15 July amount to a total of $415 \mathrm{Gg} \mathrm{C}$. The majority of the fires started after 20 June and occurred in the northern part of CA. The WRF-Chem plumerise module releases about half of the emissions within the planetary boundary layer and injects about half of them above. For comparison, anthropogenic emissions for the same time period are estimated as $328 \mathrm{Gg} \mathrm{C}$. The latter are released at the lowest model level, except for point sources where the stack height information is used to place them in the corresponding model level.

A number of synthetic $\mathrm{CO}$ tracers are included in the global and regional simulations. In the global model these include CO tracers for two different source types, fossil fuel and biofuel sources (FF) and biomass burning sources (BB), for each of the following six regions: contiguous US, Alaska and Canada, Asia, Europe and North Africa, and Central America. In the regional model we include the following three $\mathrm{CO}$ domain specific tracers: $\mathrm{CO}$ emitted from anthropogenic sources (COanthro), and wildfires (COfire) within the regional domain, and $\mathrm{CO}$ produced photochemically within the regional domain (COchem). In addition we use the global model $\mathrm{CO}$ and $\mathrm{CO}$ tracers to follow the transport of five $\mathrm{CO}$ tracers at the lateral boundaries $\mathrm{CO}$ : total $\mathrm{CO}$ inflow $(\mathrm{CObc}), \mathrm{CO}$ inflow from direct emissions from Asia (CObc_asia), the US (CObc_US), Central America (CObc_cam) and Europe and Africa (CObc_euraf).

The WRF-Chem simulations are started on 14 June 00:00 UT. After about 5 days the sum of the CO tracers (COanthro + COfire $+\mathrm{CObc}+\mathrm{COchem})$, which are set to cover all the $\mathrm{CO}$ sources, agrees to within $3 \%$ of the total $\mathrm{CO}$ at the surface. After 7 days the tracers are well spun up and the difference between the tracer sum and the total $\mathrm{CO}$ approaches zero. To avoid effects due to spin-up, all analysis that involves $\mathrm{CO}$ tracers is restricted to the time period from 20 June to 15 July.

\section{Model evaluation}

We evaluate the model simulations by comparison to three different data sets. The first includes the merged 1-min measurements of CO onboard the DC-8 (version R8) and onboard the P-3 (version R2). During ARCTAS-CARB four science flights were conducted with the DC- 8 on the following days: 18, 20, 22 and 24 June. During the 22 June flight one segment was conducted off the coast of CA to measure pollution inflow across the Pacific entering the US West Coast ("Boundary Conditions Flight"). All other flights took place over CA. For model evaluation, we also include the segments over CA of the DC-8 transit flight on 26 June. The four P-3 flights took place over CA and were conducted on 22, 24, 26 and 28 June.

CO measurements on the DC- 8 are derived from a diode laser spectrometer (Diskin et al., 2002; Sachse et al., 1987) and on the P-3 were conducted with the Carbon monOxide By Attenuated Laser Transmission (COBALT) instrument (Provencal et al., 2005). Intercomparison results for $\mathrm{CO}$ between the DC- 8 and the P-3 during ARCTAS (report available from the Tropospheric Airborne Measurements Evaluation Panel (TAbMEP) at http://www-air.larc. nasa.gov/TAbMEP.html) recommends an uncertainty of $2 \%$ for DC- 8 measurements and of $6 \%$ for the P-3 measurements.

The second observational data set used for the evaluation is the CO Total Column retrieval product from the Measurements of Pollution in the Troposphere (MOPITT) instrument aboard the NASA EOS/Terra satellite. The recently released MOPITT V4 retrievals (Deeter et al., 2010) are used for comparison of the regional and global model simulations. MOPITT V4 has been evaluated against CO in situ measurements acquired from aircraft from 2000 to 2007 . The biases are estimated as less than $1 \%$ at the surface, $700 \mathrm{hPa}$, and $100 \mathrm{hPa}$, and a bias of about $-6 \%$ at $400 \mathrm{hPa}$ (Deeter et al., 2010).

In addition to satellite and aircraft observations, we evaluate the model through comparison with data collected from surface monitoring sites throughout California from State and Local Air Monitoring Stations (SLAMS) and National Air Monitoring Stations (NAMS) networks. For the 15 June to 15 July time period there were $74 \mathrm{CO}$ monitors in operation providing hourly $\mathrm{CO}$ measurements. All monitoring was conducted using US EPA reference or equivalent methods for measuring CO (see www.epa.gov/ttn/amtic for details on these methods), and $\mathrm{CO}$ was reported in multiples of $100 \mathrm{ppbV}$, except for two monitors, which reported in multiples of $10 \mathrm{ppbV}$. The surface monitoring data used in this study is available for download from the US EPA's Air Quality System database (www.epa.gov/ttn/airs/airaqs/detaildata/ downloadaqsdata.htm). 

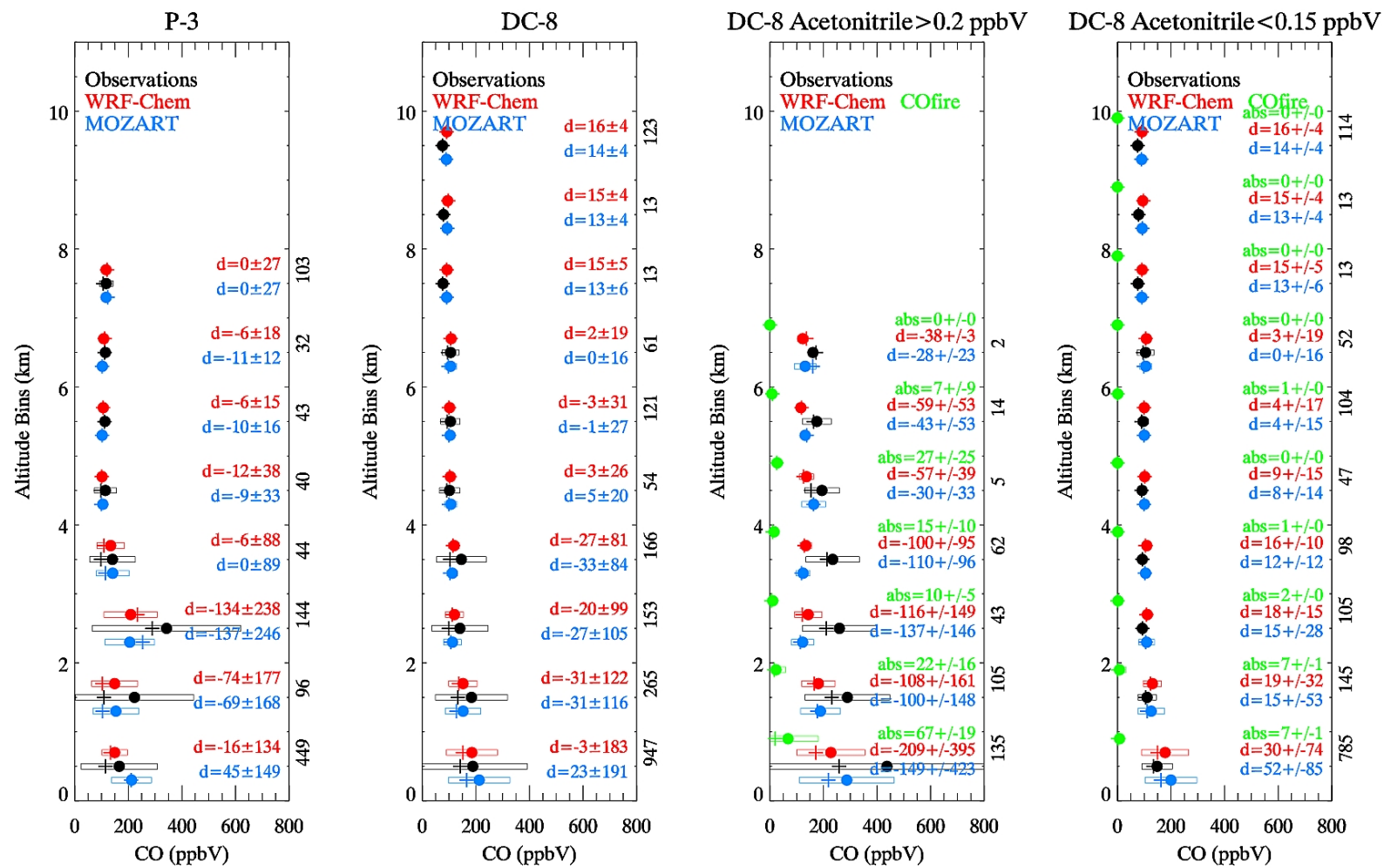

Fig. 1. Left two panels: mean (circles), median (plus signs) and standard deviation (bars) of observed (black), WRF-Chem (red) and MOZART-4 (blue) CO profiles for P-3 and DC-8 flights (excluding the boundary conditions leg on the 22 June flight). Mean difference (d) and standard deviation between model and observations is listed in each plot. The number of data points per altitude bin is specified next to the vertical axis. Right two panels: comparison for DC-8 observations, but separated into fire impacted and no fire impacted data sets based on observed acetonitrile mixing ratios. WRF-Chem fire tracer mixing ratios are shown in green and the absolute mean mixing ratios (abs) per altitude bin is listed in the graphs.

\subsection{Comparison to ARCTAS-CARB aircraft data}

For comparison to the aircraft observations, we interpolate the modeled $\mathrm{CO}$ fields to the time and location of the aircraft and average the observed and modeled $\mathrm{CO}$ fields over 1-km wide altitude bins. Evaluation results for WRF-Chem fields are listed in Table 1 and displayed in Fig. 1. In Fig. 1 we also include results for MOZART-4 because the regional model performance is in part also influenced by the boundary conditions. We show average CO profiles for the P-3 and DC-8 for all collected data, and for the DC- 8 also separate the data sets by fire influence using measurements of acetonitrile to determine observations that were significantly influenced by fire emissions (acetonitrile $>0.2 \mathrm{ppbV}$ ) and those with minor influence from fires (acetonitrile $<0.15 \mathrm{ppbV}$ ) (Warneke et al., 2006).

WRF-Chem gives a fairly good representation of the free tropospheric $\mathrm{CO}$ with mean biases generally less than $\sim 20 \mathrm{ppbV}$. Towards the lower altitudes where local emissions and local transport gain importance, the absolute model bias increases and the model generally under-predicts the observations. The variability in the observed $\mathrm{CO}$ strongly in- creases towards the lower altitudes reflecting the influence of local sources. The model captures the vertical gradient in the variability but generally underestimates the observed variability range.

Separating data by fire influence suggests that WRF-Chem specifically underestimates the $\mathrm{CO}$ emissions and mixing ratios from the CA wildfires. The model has a large negative bias for the fire influenced data set $(-142 \pm 268 \mathrm{ppbV}$ or $-30 \pm 30 \%$ ), while it shows a smaller and positive bias when compared to the no-fire data set $(23 \pm 54 \mathrm{ppbV}$ or $21 \pm 39 \%$ ). Part of the discrepancies might be related to the model missing fire plumes in the first and/or incorrectly placing them in the latter data set. The overall increased mixing ratios of COfire in the fire-influenced data set compared to the very small mixing ratios of COfire in the no-fire data set, however, strongly suggest that the model mostly captures the timing and location of fire plumes well, and that the model has an actual low bias in the $\mathrm{CO}$ mixing ratios related to fire plumes. This underestimate in fire $\mathrm{CO}$ is discussed in more detail in Sect. 3.3.

In the free troposphere WRF-Chem fields are strongly influenced by pollution inflow and both WRF-Chem and 
Table 1. Evaluation statistics for the three different WRF-Chem simulations. Listed are mean observed and modeled mixing ratios (italic bold), mean bias $(d)$ and correlation coefficient $(r)$.

\begin{tabular}{|c|c|c|c|c|c|}
\hline & & \multirow{3}{*}{$\begin{array}{l}\text { Observed } \\
325 \pm \mathbf{3 0 4}\end{array}$} & \multicolumn{3}{|c|}{ Model Simulations } \\
\hline \multicolumn{2}{|c|}{ Dataset and Units } & & \multirow{2}{*}{$\begin{array}{l}\text { Reference } \\
\mathbf{1 8 2} \pm \mathbf{9 5} \\
d=-142 \pm 268 \\
r=0.52\end{array}$} & \multirow{2}{*}{$\begin{array}{l}\text { SENS_fire } \\
211 \pm 167 \\
d=-114 \pm 247 \\
r=0.52\end{array}$} & \multirow{2}{*}{$\begin{array}{l}\text { SENS_anthro } \\
\mathbf{2 0 4} \pm \mathbf{1 2 4} \\
d=-120 \pm 281 \\
r=0.38\end{array}$} \\
\hline DC-8 fire & $(\mathrm{ppbV})$ & & & & \\
\hline DC-8 no fire & $(\mathrm{ppbV})$ & $123 \pm 52$ & $\begin{array}{l}146 \pm 75 \\
d=23 \pm 54 \\
r=0.65\end{array}$ & $\begin{array}{l}148 \pm 78 \\
d=25 \pm 60 \\
r=0.64\end{array}$ & $\begin{array}{l}162 \pm 108 \\
d=39 \pm 79 \\
r=0.72\end{array}$ \\
\hline MOPITT (domain) & $\left(1 \times 10^{16} \mathrm{~cm}^{-2}\right)$ & $181 \pm 27$ & $\begin{array}{l}176 \pm 20 \\
d=-5 \pm 14 \\
r=0.85\end{array}$ & $\begin{array}{l}177 \pm 22 \\
d=-5 \pm 14 \\
r=0.84\end{array}$ & $\begin{array}{l}177 \pm 21 \\
d=-4 \pm 14 \\
r=0.85\end{array}$ \\
\hline MOPITT (CA) & $\left(1 \times 10^{16} \mathrm{~cm}^{-2}\right)$ & $220 \pm 32$ & $\begin{array}{l}201 \pm 27 \\
d=-19 \pm 17 \\
r=0.85\end{array}$ & $\begin{array}{l}203 \pm 29 \\
d=-17 \pm 18 \\
r=0.84\end{array}$ & $\begin{array}{l}204 \pm 28 \\
d=-16 \pm 17 \\
r=0.84\end{array}$ \\
\hline Surface South & $(\mathrm{ppbV})$ & $421 \pm 215$ & $\begin{array}{l}\mathbf{4 3 2} \pm \mathbf{2 5 5} \\
d=10 \pm 350 \\
r=-0.1\end{array}$ & $\begin{array}{l}\mathbf{4 4 3} \pm \mathbf{2 5 7} \\
d=21 \pm 351 \\
r=-0.1\end{array}$ & $\begin{array}{l}\mathbf{6 4 5} \pm \mathbf{3 7 7} \\
d=223 \pm 444 \\
r=-0.1\end{array}$ \\
\hline Surface North & $(\mathrm{ppbV})$ & $408 \pm 270$ & $\begin{array}{l}247 \pm 164 \\
d=-160 \pm 284 \\
r=0.22\end{array}$ & $\begin{array}{l}300 \pm 275 \\
d=-107 \pm 328 \\
r=0.27\end{array}$ & $\begin{array}{l}338 \pm 223 \\
d=-69 \pm 323 \\
r=0.15\end{array}$ \\
\hline
\end{tabular}

MOZART-4 show a very similar behavior. At the lower altitudes the two models diverge more strongly due to localized influences. Largest differences are seen in the fire impacted data sets with MOZART-4 being higher. This is caused by MOZART-4 not considering plume rise and releasing all fire emissions at the lowest model level.

For evaluation of the global model boundary conditions and the $\mathrm{CO}$ inflow, we compare model output of $\mathrm{CO}$ over the Pacific to the ARCTAS-CARB boundary conditions flight leg that was conducted with the DC-8 on 22 June. Results for MOZART-4 and also WRF-Chem fields are shown in Fig. 2. This flight leg was not influenced by fire plumes from CA. In agreement with the WRF-Chem evaluation of flight data not influenced by fires, we see in both MOZART-4 and WRFChem a generally high bias compared to the aircraft data. Global and regional results are fairly similar as can be expected over a region that is strongly influenced by pollution inflow and little by regional and local sources. The model bias for the boundary conditions flight (Fig. 2) and the flight measurements in the free troposphere over CA (Fig. 1) exhibit a bias of about $10-20 \mathrm{ppbV}$. This suggests that a sizeable part of the bias at the lowest altitude level of $30 \mathrm{ppbV}$ for non-fire impacted observations over CA (Fig. 1) is related to the background being overestimated. The plume measured at $\sim 9 \mathrm{~km}$ is related to long-range transport from Asia (Pfister et al., 2011) but is not captured in the model. Further evaluation

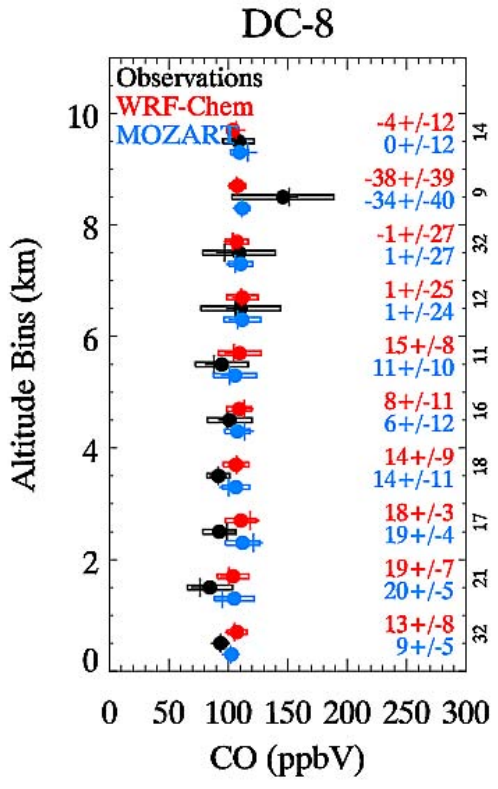

Fig. 2. Mean (circles), median (plus signs) and standard deviation (bars) of observed (black), WRF-Chem (red) and MOZART-4 (blue) CO profiles for the 22 June 2008 DC-8 Boundary Conditions Flight (ocean segment only). Mean difference and standard deviation between model and observations is specified. The number of data points per altitude bin is specified next the vertical axis. 
of the chemical boundary conditions for ARCTAS-CARB provided by the MOZART-4 simulation is given in Pfister et al. (2011).

\subsection{Comparison to MOPITT column CO}

To properly compare the CO retrievals from MOPITT to the model fields, the averaging kernel and a priori profile associated with each MOPITT retrieval has been applied to the model profiles interpolated to the time and location of the retrieval. Both the convolved model data and the MOPITT data are then averaged on a $0.25^{\circ} \times 0.25^{\circ}$ grid. Only MOPITT retrievals for daytime are used, as they generally provide a higher informational content compared to nighttime data (Deeter at al., 2010).

We evaluate the models over the entire time period 15 June-15 July 2008 since the total CO is not influenced by the spin-up time of the tracers. The conclusions remain the same as for the limited time period. Figure 3 shows the average spatial distribution of the MOPITT and WRF-Chem simulated CO columns and their differences. The CO columns are mostly representative of free tropospheric $\mathrm{CO}$, which is where the sensitivity of the MOPITT retrievals is highest. Both MOPITT and WRF-Chem show a similar spatial pattern, with clearly enhanced CO columns over the region of the fires. In agreement with the conclusions derived from the comparison to aircraft data, we find a high model bias over the ocean, but a low bias over land, where the underestimate in COfire likely contributes to the low bias. In comparing MOPITT retrievals over ocean and land it has to be considered that the retrieval sensitivity depends on the surface thermal contrast, which differs between ocean and land. Analysis of the MOPITT averaging kernels (not shown here) reveals that the comparison to MOPITT CO retrievals mostly provides an evaluation of the modeled $\mathrm{CO}$ in the lower and middle troposphere over land, and of the modeled $\mathrm{CO}$ in the upper troposphere over the ocean.

Averaged over the domain shown here, which corresponds to the WRF-Chem domain with a 1.5 degrees intent on each border, the mean difference between WRF-Chem and MOPITT is $(-5 \pm 14) \times 10^{16}$ molec $\mathrm{cm}^{2}(-2 \pm 7 \%)$ with a correlation coefficient $(r)$ of 0.85 . Selecting only retrievals over the state of CA, the mean difference is $(-19 \pm 17) \times$ $10^{16}$ molec $\mathrm{cm}^{2}(-8 \pm 7 \%)$ with $r=0.85$.

For the evaluation of the global model simulations, i.e. the chemical boundary conditions, we put the emphasis on the oceanic region to the West of the WRF-Chem domain, which is the dominant inflow region for air entering the US West Coast (Fig. 4). MOZART-4 represents the spatial pattern of MOPITT retrievals very well $(r=0.88)$, but overall has a high bias of $(13 \pm 5) \times 10^{16}$ molec $\mathrm{cm}^{2}(8 \pm 3 \%)$ in agreement with comparison to the DC-8 Boundary conditions flight.

\subsection{Comparison to monitoring data}

The evaluation of WRF-Chem and MOZART- 4 surface CO with observations at EPA monitoring sites is shown in Fig. 5. The majority of the sites (68 out of 72) are stated as being located in either urban or suburban environments. Since CO emissions are primarily associated with mobile sources, the monitoring sites are often located near strong localized pollution sources, such as busy intersections, creating a strong source-to-receptor relationship that is a challenge to duplicate in models with limited spatial resolution. Evaluation of the model is further impacted by the low resolution of the observations (multiples of $100 \mathrm{ppbV}$ with a varying detection limit of $100 \mathrm{ppbV}$ or $200 \mathrm{ppbV}$ depending on the site) and by variable temporal coverage and large data gaps, especially for early morning hours due to nightly precision and span checks. Despite these limitations, the surface observations can provide additional valuable information for evaluating the overall model performance at the surface.

The model results are interpolated to the time and location of the observations and the model precision of the total $\mathrm{CO}$ mixing ratios (not the $\mathrm{CO}$ tracers) is reduced to the lower resolution of the $\mathrm{CO}$ observations. The average time series in Figures (a) are derived by applying an 8-h running mean, and the statistics in Figures (b) and (c) are derived from individual hourly values. We further separate sites into monitoring sites located north and south of $36.5^{\circ} \mathrm{N}$. Most fires occurred in the northern part of the state, and this separation distinguishes locations primarily influenced by anthropogenic sources from locations that are more strongly influenced by fires, respectively.

At the Southern CA locations (Fig. 5, top panels) the surface $\mathrm{CO}$ mixing ratios are about $400-500 \mathrm{ppbV}$ and WRFChem represents the mean $\mathrm{CO}$ mixing ratio well with an overall high mean bias of about $10 \mathrm{ppbV}$. CO tracer contributions show a dominant influence of anthropogenic sources and a small influence from fires. The temporal variability is dominated by the diurnal variation in COanthro. The contribution from pollution inflow is around $100 \mathrm{ppbV}$ with an indication of enhanced pollution inflow towards the end of the simulation. The correlation between WRF-Chem and observations is poor and in addition to the above listed limitations in the observational data sets is explained by an overall discrepancy in the timing of peak concentrations. Both model and observations generally show an early morning and evening peak in the diurnal cycle, but while the observed peak is stronger in the morning, the evening peak in WRFChem is more pronounced. This might be caused by WRFChem incorrectly simulating the timing of the boundary layer evolution (e.g. a too rapid growth in the morning or a too rapid decay in the evening) or by errors in the temporal allocation of $\mathrm{CO}$ emissions in the emissions inventory. Future model studies are needed to better understand the cause of the discrepancy in the timing of the modeled and observed peak in CO. The correlation between modeled and observed 


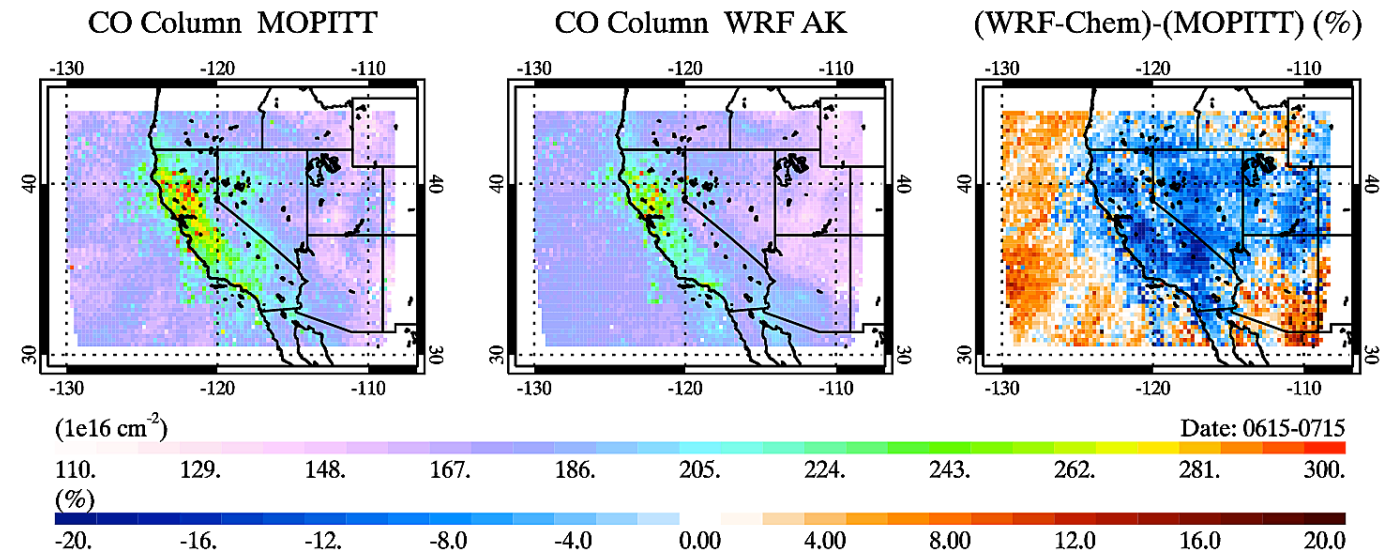

Fig. 3. CO Column retrieved from MOPITT for 15 June-15 July 2008 and corresponding WRF-Chem simulations with MOPITT operator applied. The difference plot shows the percentage difference between WRF-Chem and MOPITT.

CO Column MOPITT

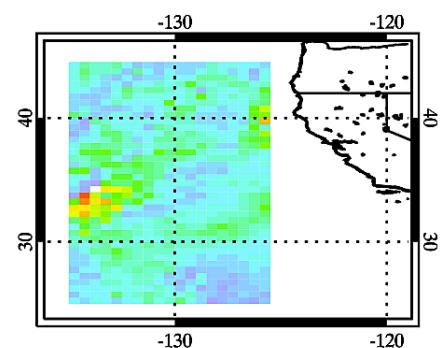

CO Column MOZART_AK

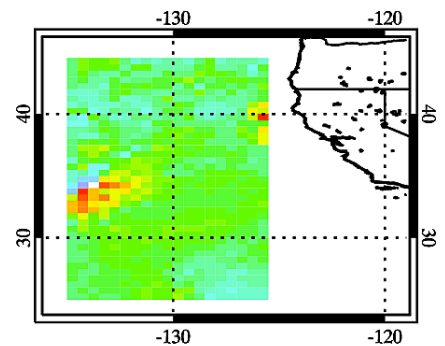

(MOZART)-(MOPITT) (\%)

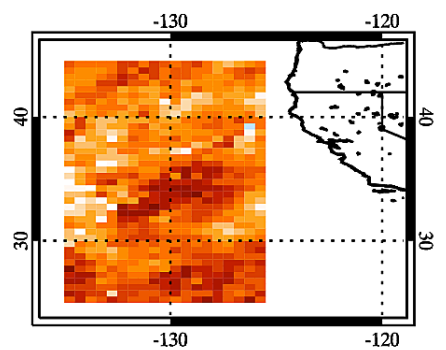

Date: $0615-0715$

\begin{tabular}{|c|c|c|c|c|c|c|c|c|c|}
\hline (1e) & & & & & & & & & Dat \\
\hline $\begin{array}{l}110 . \\
(\%)\end{array}$ & 121. & 132. & 143. & 154. & 165. & 176. & 187. & 198. & 209. \\
\hline-20. & -16. & -12. & -8.0 & -4.0 & 0.00 & 4.00 & 8.00 & 12.0 & 16.0 \\
\hline
\end{tabular}

Fig. 4. CO Column retrieved from MOPITT for 15 June-15 July, 2008 and corresponding MOZART-4 simulations with MOPITT operator applied for an oceanic region west of the WRF-Chem domain. A difference plot shows the percentage difference between MOZART-4 and MOPITT

CO improves to 0.43 if instead of an 8-h running mean daily averages are analyzed.

Simulated CO is generally lower in MOZART-4 compared to WRF-Chem, and this can be explained by the monitor site locations being located in polluted urban environments where the high urban concentrations are more diluted in the coarser resolution of the global model. This is also reflected in the frequency distributions, where WRF-Chem shows a wider range of low and moderate $\mathrm{CO}$ mixing ratios and simulates the tail of the distribution well, while MOZART-4 misses the extreme values.

For sites in Northern CA (Fig. 5, bottom panels), the average observed $\mathrm{CO}$ mixing ratios during times of little fire activity are $\sim 400 \mathrm{ppbV}$, but reach up to $\sim 700 \mathrm{ppbV}$ during intense fire episodes. WRF-Chem replicates the timing of enhanced $\mathrm{CO}$ mixing ratios during fires, but overall underestimates $\mathrm{CO}$ with a low mean bias of $-160 \mathrm{ppbV}$ with the largest differences during the first fire episode, which occurred around the last 2 weeks in June (days 173-181). CO tracer contributions reflect the increased contributions from fires at Northern CA sites and a smaller contribution from anthropogenic sources (about half of what is estimated for sites in Southern CA). For sites in Northern CA a higher correlation between modeled and measured time series is seen $(r=0.66)$. Similar to WRF-Chem, MOZART-4 underestimates $\mathrm{CO}$ during the first intense fire episode but overestimates during the second episode. Note that some of the differences between the two models are related to the fire emissions being released at the surface in MOZART-4, as well as by spreading fires over larger areas in MOZART-4, which makes it more likely that fires will impact the monitoring sites.

The underestimate of the fire emissions was also evident when comparing the FINN inventory to an independent fire 
(a) Timeseries at CO Monitoring Sites

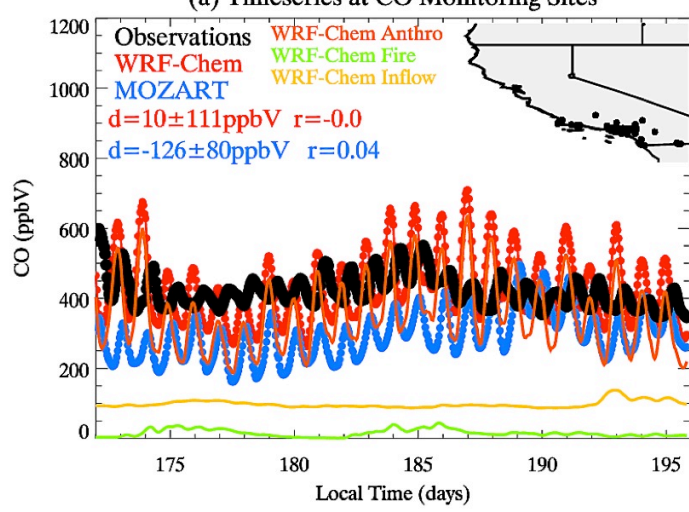

(a) Timeseries at CO Monitoring Sites

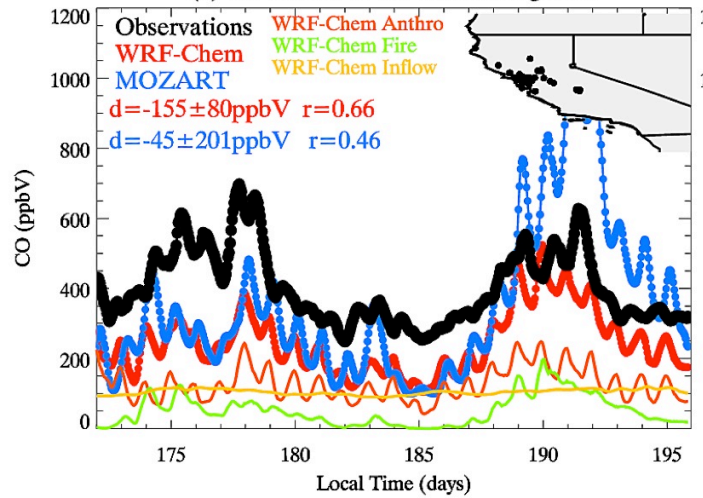

(b) Mixing Ratio

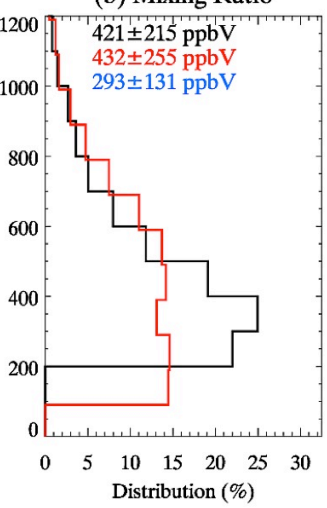

(b) Mixing Ratio

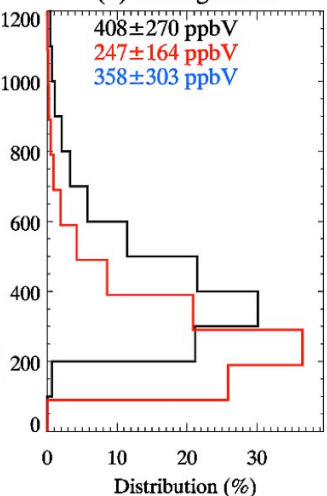

(c) Bias (Model-Obs)

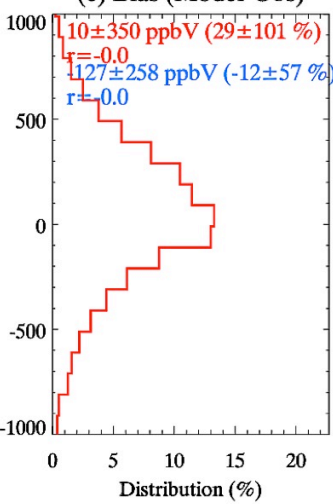

(c) Bias (Model-Obs)

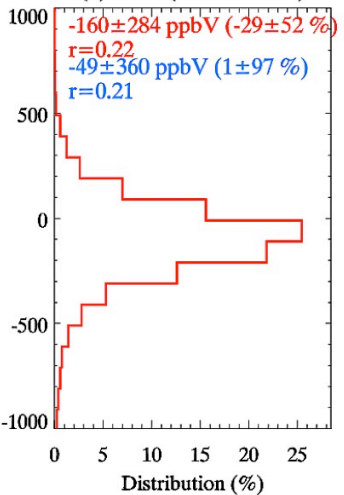

Fig. 5. Average time series (a) and hourly statistics (b and c) for observed (black) and modeled (WRF-Chem in red and MOZART-4 in blue) surface CO at monitoring sites. Upper graph: sites in Southern CA (latitudes $<36.5^{\circ} \mathrm{N}$ ). Lower graph: sites in Northern CA (latitudes $>$ $36.5^{\circ} \mathrm{N}$ ). WRF-Chem mixing ratios for CO tracers for fire (green), anthropogenic (red), and inflow (orange) are included. Time series (a) are derived by averaging hourly mixing ratios over a moving 8-h window and over all sites. The mean bias $d$ and correlation $r$ between observed and modeled time series and hourly values for 20 June-15 July is stated in the graphs.

inventory from Sonoma Technology for 15-30 June 2008 (Sean Raffuse, personal communication). This comparison indicates that over this episode the $\mathrm{CO}$ emission estimates of FINN are less than the Sonoma Technology inventory by nearly a factor 4 , while other emissions, including $\mathrm{NO}_{\mathrm{x}}$, agree much better. No comparison data was available for the second episode, but the evaluation with the surface sites indicates that emissions during the second fire episode might be underestimated to a lesser degree.

FINN estimates fire emissions using the MODIS Collection 5 Land Cover Type (LCT) product for 2005 (Friedl et al., 2010). The IGBP land cover classification is used to assign each fire pixel to one of 16 land cover/land use (LULC) classes. In Northern California, many of the fires were located in areas that were defined as Shrublands by the MODIS LCT product. Fires in this land cover class are assigned emission factors of $68 \mathrm{~g} \mathrm{CO}$ per $\mathrm{kg}$ biomass burned. Fires in forested areas in this region are assigned a higher $\mathrm{CO}$ emission factor (102-118 g CO per kg biomass burned) (Wiedinmyer et al., 2011; Akagi et al., 2011). Additionally, forest fires in FINN burn more fuel, and thus have higher emissions than shrublands. It is likely that the fires in northern California during this time period were actually burning in forested regions with much higher $\mathrm{CO}$ emissions than the model estimates. An initial evaluation of the MODIS LCT product and other land cover datasets for California (e.g. Global Land Cover 2000 product; Fritz et al., 2003) suggests that the MODIS LCT assigns much area to shrublands in California where others assign forested land cover classes. This evaluation highlights the sensitivity of the emission estimates to the various drivers used in fire emission models and provides input for future improvements of the FINN model.

The underestimate in the CO fire emissions is a limitation of the model simulations, but by having the information for $\mathrm{CO}$ tracers available and given that the $\mathrm{CO}$ chemistry is linear to first order, we can use the COfire tracer to simulate how the modeled $\mathrm{CO}$ fields would change with a four-fold time increase in fire $\mathrm{CO}$ emissions. In this case, the mean bias for surface sites in Northern CA decreases to $-3 \mathrm{ppbV}$ and also the evaluation with other observational data sets improves. For the DC- 8 fire impacted data set the mean bias improves from $-142 \mathrm{ppbV}$ to $-33 \mathrm{ppbV}$ and the 
correlation from 0.52 to 0.60 . The comparison for the nonfire impacted aircraft data, which includes some model fire plumes, is slightly worse ( $38 \mathrm{ppbV}$ and correlation of 0.58 ). The mean bias compared to MOPITT improves to $2 \pm 14 \times$ $10^{16} \mathrm{~cm}^{-2}(r=0.88)$ over the domain and to $0 \pm 22 \times 10^{16}$ $\mathrm{cm}^{-2}(r=0.83)$ over CA.

While neither model is able to represent the very localized nature of the monitoring sites, the evaluation supports the conclusions from the previous evaluations, i.e. a low model bias in $\mathrm{CO}$ from fires and smaller high bias in $\mathrm{CO}$ from anthropogenic sources and pollution inflow.

\section{Source contribution analysis for surface CO}

Keeping model limitations in mind, we use the model CO tracers to analyze the source contributions of inflow and local emissions to surface $\mathrm{CO}$ as well as boundary layer (PBL) and free tropospheric (FT) CO loadings over CA. Uncertainties in the model simulations will be addressed in Sect. 5 through analysis of a set of sensitivity simulations.

\subsection{Average source contributions for surface $\mathrm{CO}$ over California}

Figure 6 displays time series of surface mixing ratios of total $\mathrm{CO}$ and $\mathrm{CO}$ tracers averaged over the region of CA. Even though our analysis focuses on the time period after model spinup, we show here the results for the entire time period of the WRF-Chem simulation to illustrate the buildup of the $\mathrm{CO}$ tracer with time. In addition to providing results for the actual simulation, we also list estimates for a four-fold increase in $\mathrm{CO}$ fire emissions to correct for the low bias in our fire emission inventory and provide an upper limit of the fire impact.

The average $\mathrm{CO}$ surface mixing ratios over $\mathrm{CA}$ are on the order of 200-300 ppbV and reach up to $500 \mathrm{ppbV}$ (as high as $1.7 \mathrm{ppbV}$ for a four-fold increase in COfire) after the fires begin. The mixing ratios show a strong diurnal cycle, which is also seen in the time series of COanthro and COfire reflecting diurnal variations in emissions, boundary layer dynamics and photochemistry. COanthro average mixing ratios contribute about 50-100 ppbV to surface $\mathrm{CO}$ with little day-to-day variability, and a spatial variability (expressed by the standard deviation) of around $100 \mathrm{ppbV}$. In comparison, the temporal and spatial variability in COfire is clearly higher. Average mixing ratios increase from near zero up to $\sim 200 \mathrm{ppbV}$ when the fires start and reach nearly $400 \mathrm{ppbV}$ during the most intense fire period reflecting the localized nature of this source term. The spatial variability is about a factor of 2-3 higher than the average mixing ratios. COchem is a relatively small contribution to the total $\mathrm{CO}$, but shows pronounced changes over time. The increase in COchem over the simulation period follows the temporal evolution of the fires suggesting that the increases over the time period are to some extent re-
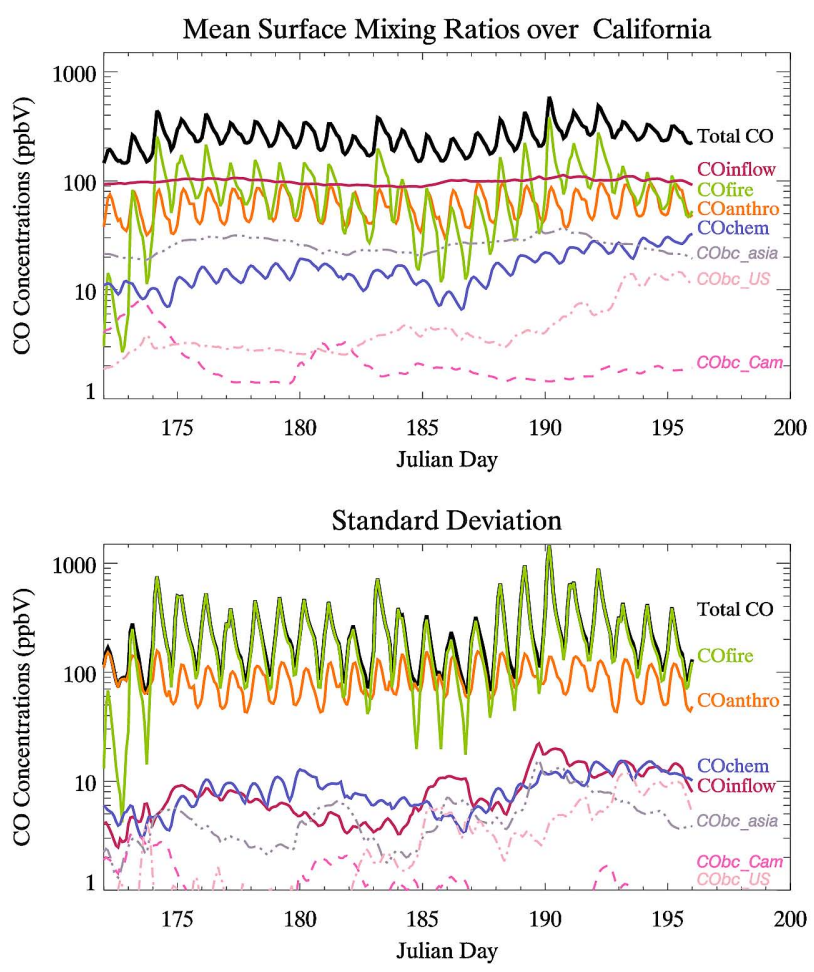

Fig. 6. Time series of simulated average total $\mathrm{CO}$ and $\mathrm{CO}$ tracer surface mixing ratios over CA. Shown are the mean and standard deviation over the time period 20 June-15 July. Note the logarithmic scale.

lated to photochemical CO production from fire-emitted hydrocarbons.

In contrast to the local sources, the inflow of $\mathrm{CO}(\mathrm{CObc})$ does not show a strong diurnal cycle, relatively less spatial variability and adds approximately $100 \mathrm{ppbV}$ to the surface $\mathrm{CO}$. The temporal evolution shows events of elevated and reduced inflow varying over a range of about $20 \mathrm{ppbV}$. CObc mostly reflects a "CO background" where about half can be attributed to photochemically produced $\mathrm{CO}$ and half to $\mathrm{CO}$ from direct emissions (Granier et al., 1999; Horowitz et al., 2003; Pfister et al., 2004). CObc_asia is the major contributor to the $\mathrm{CO}$ inflow from direct emissions with up to $\sim 35 \mathrm{ppbV}$ and correlates well with the temporal patterns of CObc. CObc_cam and CObc_US account for a smaller part of the $\mathrm{CO}$ inflow. Towards the end of the time period the CObc_US tracer shows a clear increase. Analysis of the MOZART-4 CO tracer transport (not shown here) indicates that some of the pollution from within the domain is transported towards the West over the ocean and then circles back into the domain; this is particularly evident in the transport of US fire plume. CO from sources in Europe and Africa (not shown here) has a rather small influence and variability (on average $4 \pm 1 \mathrm{ppbV}$ ).

The contributions from the most relevant source terms are summarized in Table 2 and in Fig. 7. Frequency distributions 
Table 2. Source contribution statistics for the three different WRFChem simulations.

\begin{tabular}{|c|c|c|c|c|}
\hline & & \multicolumn{3}{|c|}{ Model Simulation } \\
\hline & & Reference & SENS_fire & SENS_anthro \\
\hline \multicolumn{5}{|c|}{ Average Mixing Ratios in (ppbV) } \\
\hline \multirow{6}{*}{ Surface Mixing Ratio } & Total CO & $260 \pm 308$ & $343 \pm 608$ & $286 \pm 324$ \\
\hline & COanthro & $61 \pm 95$ & $61 \pm 95$ & $87 \pm 149$ \\
\hline & COfire & $84 \pm 294$ & $168 \pm 601$ & $84 \pm 294$ \\
\hline & COchem & $16 \pm 11$ & $17 \pm 12$ & $15 \pm 10$ \\
\hline & $\mathrm{CObc}$ & $99 \pm 11$ & $99 \pm 11$ & $99 \pm 11$ \\
\hline & COasia & $26 \pm 7$ & $26 \pm 7$ & $26 \pm 7$ \\
\hline \multirow[t]{6}{*}{ PBL Mixing Ratio } & Total CO & $237 \pm 223$ & $305 \pm 431$ & $260 \pm 239$ \\
\hline & COanthro & $53 \pm 80$ & $53 \pm 80$ & $76 \pm 125$ \\
\hline & COfire & $70 \pm 208$ & $137 \pm 424$ & $70 \pm 208$ \\
\hline & COchem & $16 \pm 11$ & $17 \pm 12$ & $15 \pm 10$ \\
\hline & CObc & $99 \pm 11$ & $99 \pm 11$ & $99 \pm 11$ \\
\hline & COasia & $26 \pm 7$ & $26 \pm 7$ & $26 \pm 7$ \\
\hline \multirow[t]{6}{*}{ FT Mixing Ratio } & Total CO & $130 \pm 37$ & $137 \pm 56$ & $133 \pm 38$ \\
\hline & COanthro & $8 \pm 9$ & $8 \pm 9$ & $11 \pm 13$ \\
\hline & COfire & $18 \pm 31$ & $25 \pm 50$ & $18 \pm 31$ \\
\hline & COchem & $8 \pm 7$ & $8 \pm 7$ & $8 \pm 6$ \\
\hline & $\mathrm{CObc}$ & $96 \pm 7$ & $96 \pm 7$ & $96 \pm 7$ \\
\hline & COasia & $25 \pm 5$ & $25 \pm 5$ & $25 \pm 5$ \\
\hline \multicolumn{5}{|c|}{ Average Mixing Ratio Contributions (\%) } \\
\hline \multirow[t]{5}{*}{ Surface Contribution } & COanthro & $22 \pm 18$ & $21 \pm 18$ & $26 \pm 21$ \\
\hline & COfire & $18 \pm 22$ & $24 \pm 26$ & $17 \pm 22$ \\
\hline & COchem & $8 \pm 4$ & $7 \pm 4$ & $7 \pm 4$ \\
\hline & $\mathrm{CObc}$ & $53 \pm 21$ & $49 \pm 23$ & $50 \pm 22$ \\
\hline & COasia & $14 \pm 6$ & $12 \pm 6$ & $13 \pm 6$ \\
\hline \multirow[t]{5}{*}{ PBL Contribution } & COanthro & $21 \pm 17$ & $19 \pm 17$ & $25 \pm 20$ \\
\hline & COfire & $17 \pm 21$ & $23 \pm 26$ & $17 \pm 21$ \\
\hline & COchem & $8 \pm 4$ & $7 \pm 4$ & $7 \pm 4$ \\
\hline & $\mathrm{CObc}$ & $54 \pm 21$ & $51 \pm 23$ & $52 \pm 22$ \\
\hline & COasia & $14 \pm 6$ & $13 \pm 6$ & $13 \pm 6$ \\
\hline \multirow[t]{5}{*}{ FT Contribution } & COanthro & $6 \pm 5$ & $6 \pm 5$ & $8 \pm 8$ \\
\hline & COfire & $11 \pm 13$ & $12 \pm 16$ & $11 \pm 13$ \\
\hline & COchem & $6 \pm 4$ & $6 \pm 4$ & $5 \pm 4$ \\
\hline & $\mathrm{CObc}$ & $78 \pm 16$ & $77 \pm 18$ & $77 \pm 16$ \\
\hline & COasia & $20 \pm 5$ & $20 \pm 6$ & $20 \pm 5$ \\
\hline
\end{tabular}

are calculated for individual grid cells over the entire region of CA for the 2-h model output over the time period 20 June15 July 2008. The absolute and relative contributions are displayed. The largest single average contribution comes from CObc with a mean absolute mixing ratio of $99 \pm 11 \mathrm{ppbV}$; $26 \pm 7 \mathrm{ppbV}$ of this can be attributed to direct emissions from Asia, which is in the range of the study by Liang et al. (2004), who estimate the mean summertime Asian contribution at Cheeka Peak $\left(48.3^{\circ} \mathrm{N}, 124.63^{\circ} \mathrm{W}\right)$ as $24 \mathrm{ppbV}$. COanthro mixing ratios are $61 \pm 95 \mathrm{ppbV}$ on average, which is smaller than the average contributions from COfire $(84 \pm 294 \mathrm{ppbV}$ or $337 \pm 1177 \mathrm{ppbV}$ for a four-fold increase in COfire). The domain specific sources show a much larger standard deviation compared to the inflow with COfire being by far the most variable term. This is expected because the inflow contributes more strongly to the overall background, while the local source strengths are much more dependent on their specific location. In addition, COchem also reflects a localized nature with a relatively large standard deviation compared to its much smaller mean contribution $(16 \pm 11 \mathrm{ppbV})$. The range for the absolute contributions spanned by the 1090th percentiles are 88-113 ppbV for CObc compared to 8-131 ppbV for COanthro, 1-172 ppbV (4-690 ppbV for a four-fold increase) for COfire and 5-32 ppbV for COchem.

Looking at the percentage contributions, the picture changes and the range for $\mathrm{CO}$ inflow becomes comparable to that for the regional tracers. On average, $53 \pm 21 \%$ ( $42 \pm 24 \%$ for a four-fold COfire increase) of total surface $\mathrm{CO}$ is related to pollution inflow and in some areas inflow accounts for over $80 \%$ of the total CO (the 90th percentile for CObc contributions is $81 \%$ ) while in others it contributes less than $20 \%$ (the 10th percentile is $23 \%$ ). Average contributions of local anthropogenic and fire emissions are $22 \pm 18 \%$ and $18 \pm 22 \%$, respectively $(18 \pm 17 \%$ and $34 \pm 29 \%$, respectively for a four-fold COfire increase). The corresponding 10th and 90th percentile ranges are 4-50\% and $1-52 \%$. COchem is estimated to add $8 \pm 4 \%$ to the surface CO and only $1 \%$ of the data have a relative contribution of larger than $19 \%$. Average relative contributions for the individual inflow sources are estimated as $14 \pm 6 \%$ for CObc_asia, $2 \pm 3 \%$ for CObc_US (not shown), $2 \pm 1 \%$ for CObc_euraf (not shown) and $1 \pm 2 \%$ for CObc_cam (not shown).

\subsection{Spatial distribution of surface source contributions}

The surface average mixing ratios of $\mathrm{CO}$ and $\mathrm{CO}$ tracers averaged over 20 June-15 July of total $\mathrm{CO}$ and $\mathrm{CO}$ tracers are displayed in Fig. 8. Note that the color scales are on a logarithmic scale and change between the graphs. Our analysis focuses mostly on CA, but the entire modeling domain is shown. To support interpretation of the results we also include a map of the domain topography.

The total surface CO distribution demonstrates high mixing ratios over large parts of CA with hotspots around Los Angeles and south of San Francisco as well as in the northern part of the state. The anthropogenic tracer shows that high $\mathrm{CO}$ around Los Angeles is related to local emissions from fossil fuel and biofuel sources with elevated $\mathrm{CO}$ also seen around the Bay area and throughout the Central Valley. The CO hotspots in Northern CA and south of the Bay Area are related to wildfires as illustrated by the COfire distribution, with the prevalent transport of fire plumes towards the east and southeast. High values for COchem are found around regions with high local emissions. $\mathrm{CO}$ precursors are transported during the time it takes to chemically produce $\mathrm{CO}$, which causes the spatial patterns to be more widespread around the emission sources.

Boundary conditions have an impact over large parts of $\mathrm{CA}$, with a major contribution from COasia. High CObc_US values near the southern border of the domain have to be 

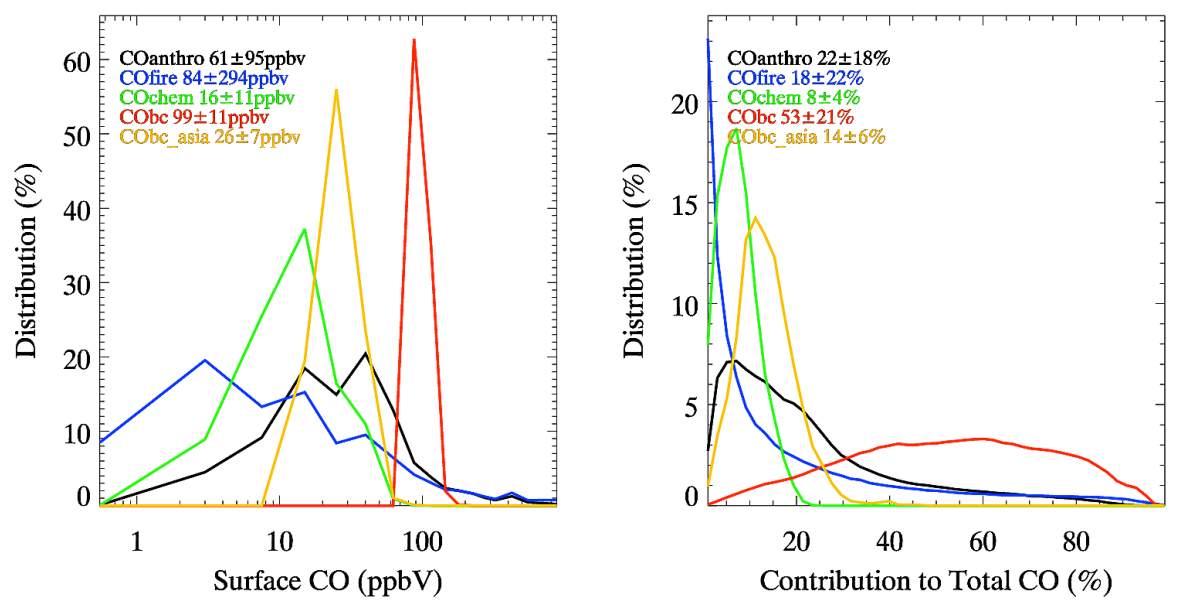

Fig. 7. Frequency distribution of $\mathrm{CO}$ tracer mixing ratios (ppbV) (left-hand side) and relative contributions (\%) (right-hand side) for surface CO over CA for 20 June-15 July.
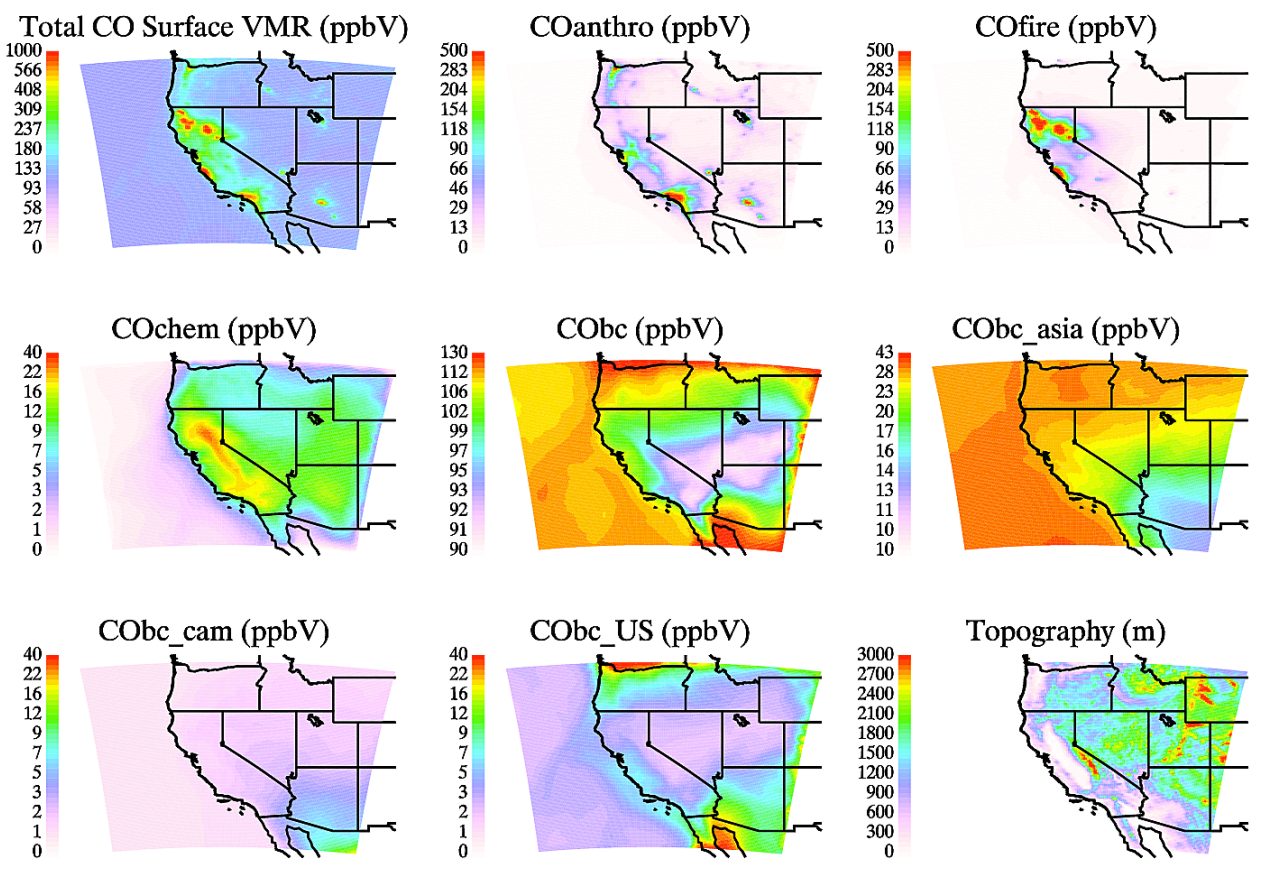

Fig. 8. Maps of surface mixing ratios (ppbV) of total CO and CO tracers averaged for 20 June-15 July and of domain topography (m).

interpreted with caution. The regions for the MOZART-4 $\mathrm{CO}$ tracers were selected for rectangular shaped areas and the separation between the US and Central America domains was set at $30^{\circ} \mathrm{N}$ meaning that emissions from Northern Mexico are assigned to CObc_US. The topography over CA causes complex horizontal and vertical transport patterns that mix air from higher altitudes to the surface. $\mathrm{CObc}$ has largest values in the Northern part of the state and around and inland of the Bay Area and into the Central Valley. Huang et al. (2011) found a similar spatial pattern for CO from Chi- nese emissions. Areas of high CObc are not necessarily correlated with regions of high elevations even though the latter are typically considered as representative for inflow. The transport of inflow to the surface is discussed in more detail in the next Section.

\subsection{General transport pathways for pollution inflow}

In order to analyze the pathways that bring pollution inflow down to the surface over CA we look more closely at the CObc_asia tracer. Figure 9 shows $C O b c \_a s i a$ mixing ratios 

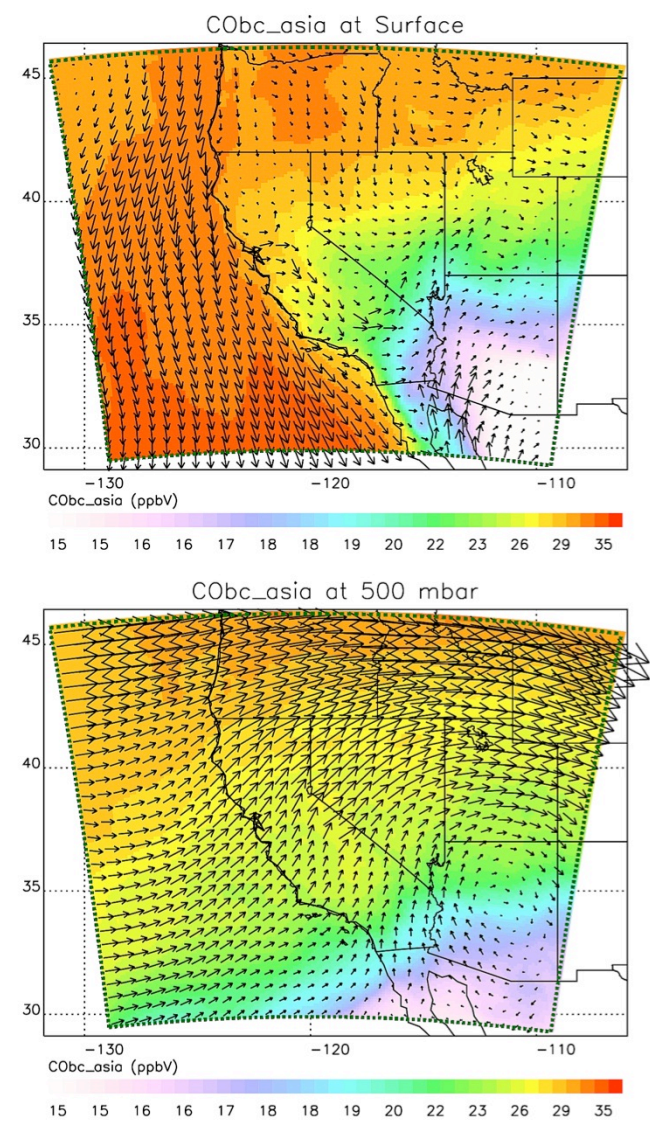
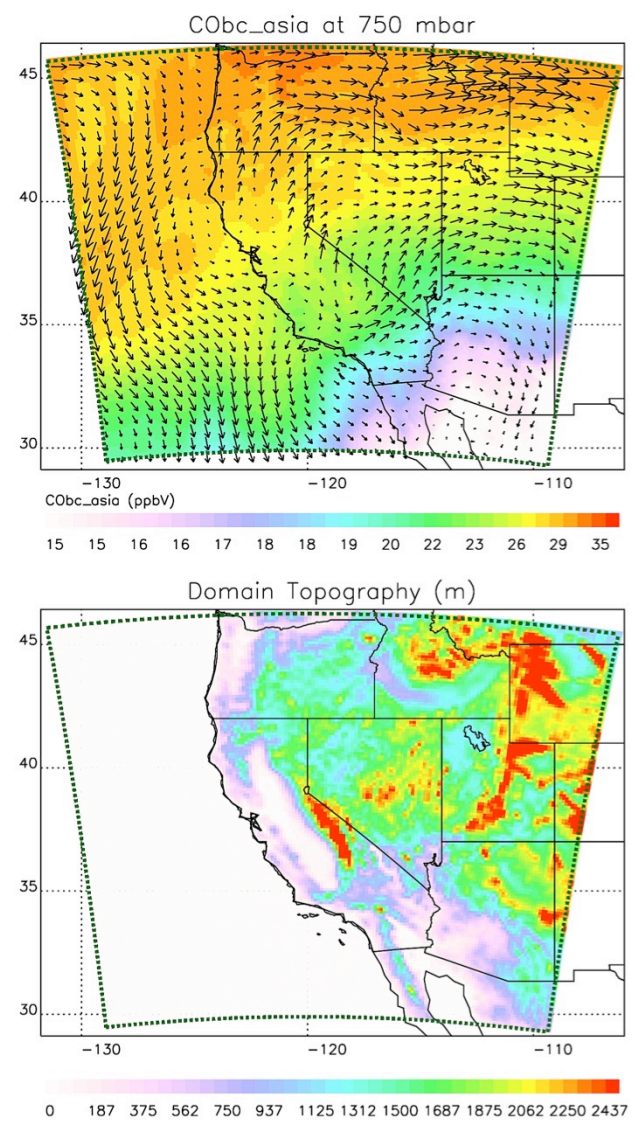

Fig. 9. Average CObc_asia mixing ratios and wind fields for 20 June-15 July at the surface, $750 \mathrm{mbar}(\sim 1.6 \mathrm{~km})$ and $500 \mathrm{mbar}(\sim 4 \mathrm{~km})$ model levels. The domain topography is shown in the bottom right panel.

and wind fields at the surface, $750 \mathrm{mbar}$ and 500 mbar averaged for 20 June-15 July 2008 together with domain topography. At the lower altitudes, where we find the largest mixing ratios, CObc_asia is largely entering the domain from the North and is transported southwards along the coast. As also described by Parrish et al. (2010), Fig. 9 shows that surface air can enter at the Carquinez Strait in the Bay area where it splits northward into the Sacramento and southward into the San Joaquin Valley. Separate analysis for daytime and nighttime (not shown here) shows that along the Californian coastline, the sea breeze brings high CObc_asia onshore during the day, while the off-shore flow during the nighttime land breeze is smaller due to lower windspeeds. In the free troposphere $(500 \mathrm{mbar}$ ) the flow entering the domain is predominantly from the west changing to a more southwesterly direction over land.

The tagged tracers from the global model, where anthropogenic and fire Asian sources are separate tags, can give an understanding of different source regions. Analysis of the global tracers (not shown here) shows that the main source for fires in Asia this time of the year is at higher latitudes (above $\sim 40^{\circ} \mathrm{N}$ ) and these emissions are predominately transported at lower altitudes towards the US West Coast. In con- trast, Asian anthropogenic $\mathrm{CO}$ with the major source regions at lower latitudes shows the highest mixing ratios at altitudes above $5 \mathrm{~km}$, but also significant contributions near the surface. The near-surface mixing ratios of the global model Asian fire tracer over the Eastern Pacific is on the order of 15-20 ppbV compared to $12-15 \mathrm{ppbV}$ for the anthropogenic tracer. The importance of low level transport pathways for Asian CO during summertime has also been discussed by Liang et al. (2004) and Holzer et al. (2007). In summertime the Asian transport is highest at latitudes around $40^{\circ} \mathrm{N}$ (Fig. 9), which is further north compared to springtime when Asian export is at its maximum and the major transports occurs at around $35^{\circ} \mathrm{N}$ (Stohl et al., 2002; Liang et al., 2004).

To illustrate the vertical transport of CObc_asia, we show in Fig. 10 vertical West-East cross-sections $\left(130^{\circ} \mathrm{W}\right.$ to $116^{\circ} \mathrm{W}$ ) along different latitudes. The cross section at $38^{\circ} \mathrm{N}$ shows that, in addition to the discussed transport of CObc_asia from the Carquinez Strait into the Sacramento Valley, there is also downward transport of inflow bringing air masses from altitudes below about $2-3 \mathrm{~km}$ to the surface in the Sacramento Valley, while airmasses at higher altitudes mostly remain at those altitudes. A similar picture is given by the $40.5^{\circ} \mathrm{N}$ cross-section through the Northern 

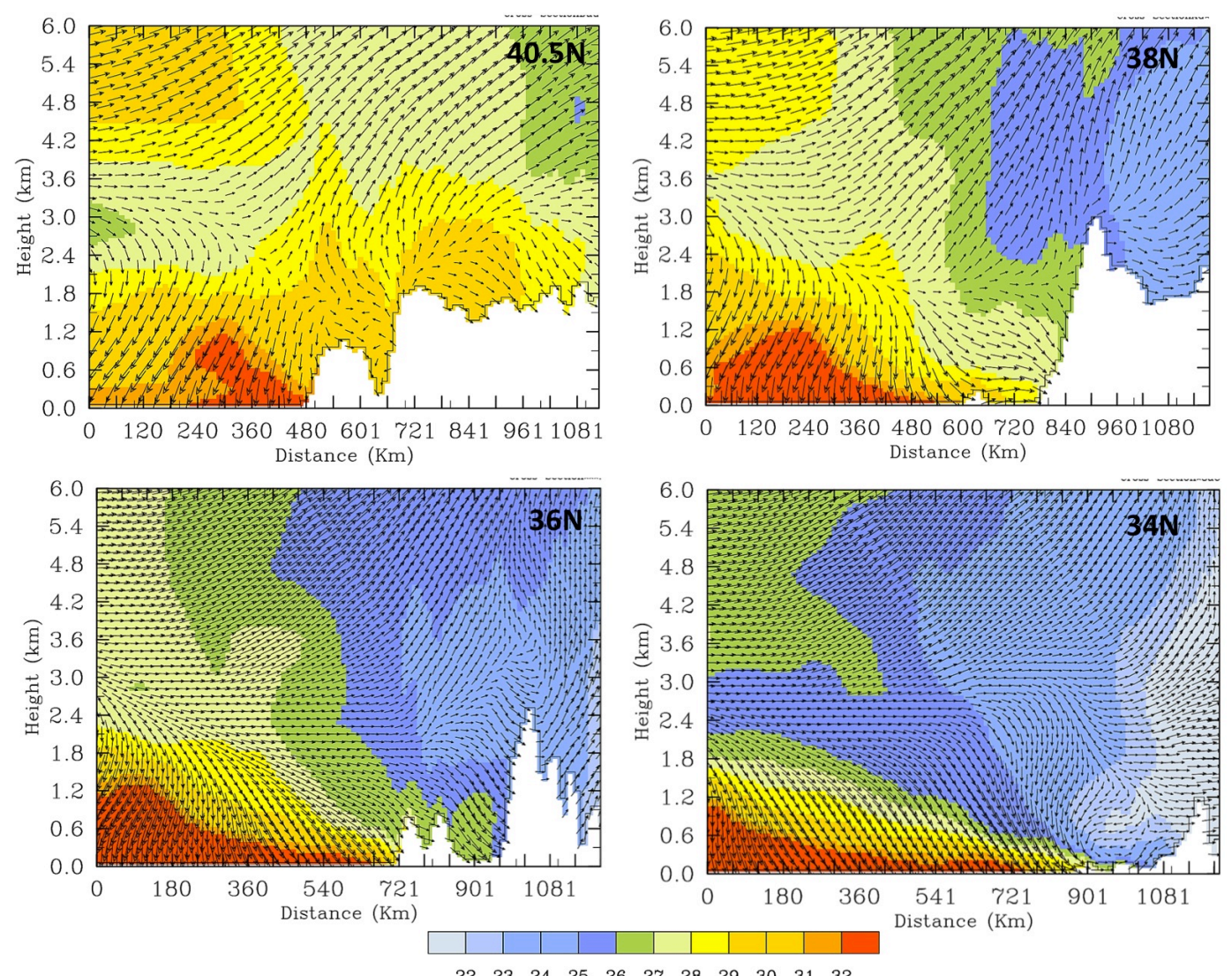

Fig. 10. Longitude - Altitude Cross Sections of CObc_asia (ppbV) along $130-116^{\circ} \mathrm{W}$ at four different latitudes, averaged over 20 June-15 July 2008: $40.5^{\circ} \mathrm{N}$ (top left), $38^{\circ} \mathrm{N}$ (top right), $36^{\circ} \mathrm{N}$ (bottom left) and $34^{\circ} \mathrm{N}$ (bottom right).

Sacramento Valley where some of the highest surface ozone concentrations in California are monitored (Parrish et al., 2010). These transport patterns support the study by Parrish et al. (2010), who postulate that in addition to northward low altitude transport in the Sacramento Valley downward transport of pollution aloft might add to elevated pollution levels. Similar conclusions were also drawn by Huang et al. (2010). At the lower latitudes $\left(34^{\circ} \mathrm{N}\right.$ and $\left.36^{\circ} \mathrm{N}\right)$, we do find a similar pattern, but with a more pronounced vertical gradient and smaller mixing ratios over the continent. The downward transport of CObc_asia, similar to that seen in Northern California, is strongest for airmasses below about $3 \mathrm{~km}$.

\subsection{Influence of pollution inflow from global and regional modeling}

To date, most studies that provide estimates about the impact of intercontinental pollution transport on local and regional air quality have been based on global modeling ( $\mathrm{Li}$ et al., 2002; Liang et al., 2004; Liu et al., 2008; Fiore et al., 2009; Reidmiller et al., 2009). Our tagged global and regional model simulations allow us to examine differences that arise between using a global versus a higher resolution regional model. For this purpose we focus the analysis mostly on the Asian CO tracers, which are directly comparable between the MOZART-4 and the WRF-Chem simulation.

Overall the tagged source contributions for surface $\mathrm{CO}$ over CA are comparable between the global and the regional model, and the different model resolutions as well as different model physics and the slightly different tracer tagging approach (e.g. anthro and fire emissions in MOZART-4 are tagged for the entire contiguous US) lead to rather small differences. COanthro contributes $55 \pm 74 \mathrm{ppbV}$ in MOZART4 versus $61 \pm 95 \mathrm{ppbV}$ in WRF-Chem, while fires contribute $180 \pm 402 \mathrm{ppbV}$ and $84 \pm 294 \mathrm{ppbV}$ for the two model simulations, respectively. For the latter, it is more representative to compare MOZART-4 to SENS_fire, where the fire emissions are also released at the surface level $(168 \pm 601 \mathrm{ppbV})$.

As was discussed in Sect. 4.1, the contribution of CObc_asia to surface $\mathrm{CO}$ mixing ratios over $\mathrm{CA}$ is on average $26 \pm 7 \mathrm{ppbV}(14 \pm 6 \%$ for the reference run and $12 \pm 6 \%$ for the SENS_fire case) for the WRF-Chem simulations. The same statistics for MOZART-4 results reveal similar results in regard to absolute mixing ratios $(25 \pm 7 \mathrm{ppbV})$ and a slightly smaller relative contribution $(10 \pm 6 \%)$. Also the analysis of the extreme values shows very similar statistics. 


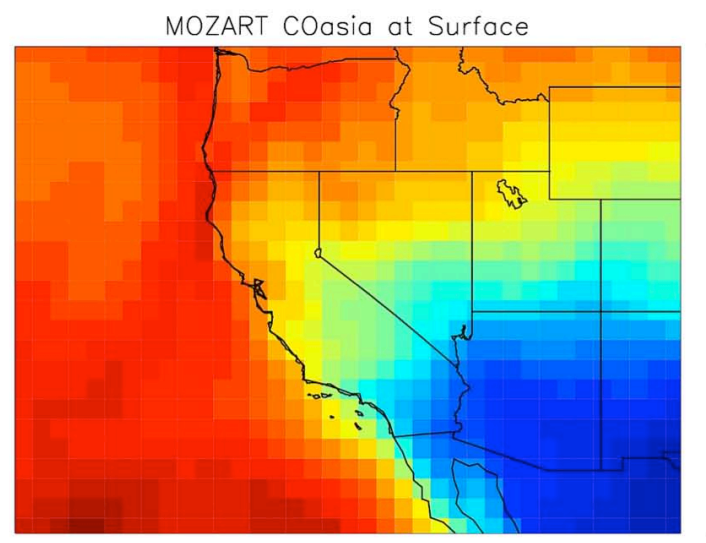

COosio (ppbV)

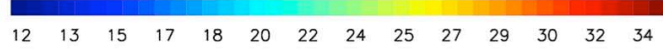

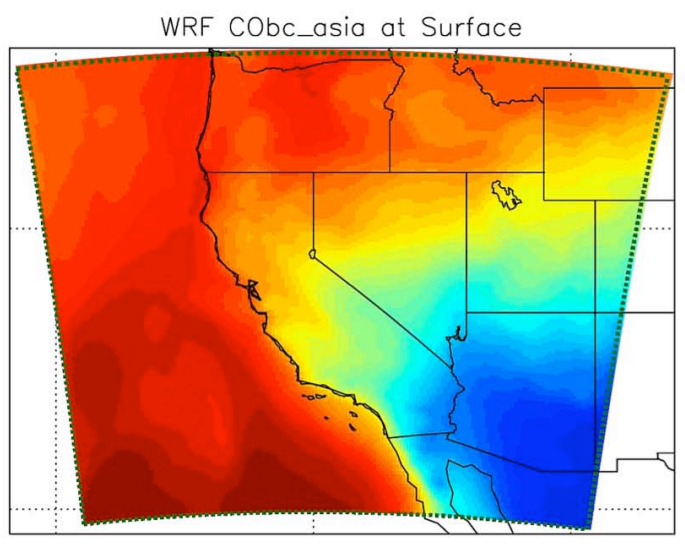

CObc_asia (ppbv)

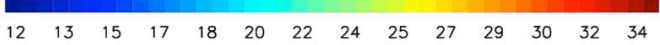

Fig. 11. Average COasia surface mixing ratios (ppbV) from MOZART-4 (left) and WRF-Chem for 20 June-15 July.

In both WRF-Chem and MOZART-4 we find similar upper percentiles: $1 \%$ of the Asian $\mathrm{CO}$ tracer mixing ratios are larger than $51 \mathrm{ppbV}$ and $10 \%$ of the Asian $\mathrm{CO}$ tracer mixing ratios are larger then $33 \mathrm{ppbV}$.

The average surface distribution of the Asian $\mathrm{CO}$ tracers from the WRF-Chem and MOZART-4 simulations is compared in Fig. 11. Differences are seen over the ocean, where WRF-Chem shows higher values indicating a stronger southward and downward transport of Asian CO compared to MOZART-4. Over the region of CA the distributions of both models are very similar and the global model despite reduced spatial resolution closely resembles the features seen in the regional simulation. There are, however, some discrepancies in the details. Specifically over the Central Valley the higher spatial resolution of WRF-Chem shows a more pronounced impact from pollution inflow compared to MOZART-4.

Generally one would expect that global models smooth concentration fields more strongly compared to a higher resolution model, and this is certainly the case in simulating local emission sources. The results from our study, however, let us conclude that, for the given model setup with a relatively high spatial resolution, statistically global simulations can provide a reasonable representation of the influence of long-range transport on regional air quality, at least for $\mathrm{CO}$ or other tracer species with a fairly simple chemistry (e.g. primary particulate matter). This would further lead to the hypothesis that in estimating the influence of long-range pollution transport on local air quality, the general underestimation of intense pollution plumes in global models, which was discussed in a previous study (Pfister et al., 2011) is likely a bigger concern than is the model resolution, because those pollution plumes are directly translated into the boundary conditions for regional models.

\section{Average contributions for the boundary layer and the free troposphere}

In addition to the previous analysis of surface $\mathrm{CO}$, we also examine the $\mathrm{CO}$ tracer burdens integrated over the PBL (surface to top of the modeled PBL height) and integrated over the FT (top of the modeled PBL height to $6 \mathrm{~km}$ ). We choose here an upper limit of $6 \mathrm{~km}$, but the general conclusions remain the same if we instead move the upper bound to $8 \mathrm{~km}$ or $10 \mathrm{~km}$.

The daily average burden over CA for the time period 20 June-15 July is $0.020 \mathrm{Tg}$ CO for the PBL and 0.19 Tg CO for the FT. The burden amounts can have significant dayto-day variability. The total $\mathrm{CO}$ burden for individual days varies between about $0.015-0.025 \mathrm{Tg} \mathrm{CO}$ in the PBL and between $0.16-0.25 \mathrm{Tg} \mathrm{CO}$ in the FT with COfire being a major driver of this variability. On average, the inflow of $\mathrm{CO}$ makes up for $52 \%$ of the total CO burden in the PBL and an even higher percentage (73\%) in the FT. (For a four-fold increase in fire emissions these contributions are $31 \%$ and $52 \%$, respectively.) For domain specific sources the reverse is the case and we find higher contributions in the PBL compared to the FT: fires account for $23 \%$ in the PBL compared to $14 \%$ in the FT, anthropogenic emissions explain $17 \%$ in the PBL compared to $6 \%$ in the FT and COchem contributes $8 \%$ in the PBL versus $6 \%$ in the FT. (For a four-fold increase in fire emissions we estimate the fire contribution as $54 \%$ and $40 \%$, the anthropogenic contributions as $10 \%$ and $4 \%$ and the COchem contributions as $5 \%$ and $4 \%$ in the PBL and FT, respectively.)

The calculated burden amounts are influenced by the actual CO loadings but also by varying heights of the PBL. To account for the latter and allow a more direct comparison to the surface mixing ratio, we further provide statistics for the average mixing ratios (column of $\mathrm{CO}$ divided by the 
air column). The average mixing ratios in the PBL over CA are of similar order as the values estimated for surface $\mathrm{CO}$ (Table 2): $53 \pm 80 \mathrm{ppbV}$ for COanthro, $70 \pm 208 \mathrm{ppbV}$ for COfire, $16 \pm 11 \mathrm{ppbV}$ for COchem, $99 \pm 11 \mathrm{ppbV}$ for CObc. In comparison, COanthro in the FT is reduced to $8 \pm 9 \mathrm{ppbV}$, COfire to $18 \pm 31 \mathrm{ppbV}$, and COchem to $8 \pm 7 \mathrm{ppb}$. The CObc average mixing ratios of $96 \pm 7 \mathrm{ppbV}$ in the FT is similar to the PBL value. The total CO mixing ratio, however, is significantly lower in the FT $(130 \pm 37 \mathrm{ppbV})$ than in the PBL $(237 \pm 223 \mathrm{ppbV})$ explaining the higher relative influence of $\mathrm{CObc}$ in the FT.

\section{Sensitivity simulations}

Uncertainties in the $\mathrm{CO}$ emissions, as well as the transport, will affect the distribution of modeled $\mathrm{CO}$ and indirectly $\mathrm{OH}$, the CO sink. Thus, differences between modeled distributions and budgets are a result of differences in emissions, transport and chemical schemes. While a comprehensive analysis of all possible sources of uncertainty is beyond the scope of this work, we look into changes in the $\mathrm{CO}$ budget estimates for two likely modeling scenarios. These additional simulations are targeted towards examining the sensitivity of tracer contributions to changes in the treatment of fires and to changes in anthropogenic emissions, respectively.

In the first simulation (SENS_fire), we changed the treatment of fire emissions from having them distributed vertically through the online plumerise module to emitting them at the lowest model level only. Most chemical transport models either release fire emissions at the surface or use predefined injection heights. This simulation provides a range for how modeled $\mathrm{CO}$ fields might change for different treatments of injection height.

In a second simulation (SENS_anthro) we modified the anthropogenic emissions from using the CARB emission inventory over CA to using the EPA NEI-2005 inventory for the entire modeling domain. Total anthropogenic emissions in the latter simulation increase from $328 \mathrm{Gg} \mathrm{CO}$ to $391 \mathrm{Gg} \mathrm{C}$. The higher total emissions in the NEI inventory are to some part explained by the fact that it is targeted for the year 2005, while the CARB inventory has been projected to the year 2008 reflecting reductions in emissions over these years.

The evaluation results for the sensitivity simulations are compared to the reference run in Table 1 . When compared to the DC-8 aircraft measurements, the average bias for the nofire data selection for SENS_fire is similar to the reference simulation, as expected, but increases to $39 \pm 79 \mathrm{ppbV}$ for SENS_anthro indicating a high bias in the NEI EPA emissions inventory. In many modeling studies anthropogenic emissions often are held constant over the course of multiple years, but our results demonstrate the importance of considering year-specific emission inventories, also for anthropogenic sources.
For the fire impacted data set, both SENS_fire and SENS_anthro show a reduced mean bias of $-114 \pm$ $247 \mathrm{ppbV}$ and $-120 \pm 281 \mathrm{ppbV}$, respectively. This, however, does not imply a better performance in either of the sensitivity simulations over the reference simulation. Considering the likely low bias in fire emissions, the improved bias in SENS_fire is assumed to be due to a combination of an increase in model $\mathrm{CO}$ at low altitudes by releasing fire emissions at the surface and the dominance of aircraft observations at low altitudes (Fig. 1). The improved mean bias in SENS_anthro for the fire impacted data set likely results from the increased bias in anthropogenic $\mathrm{CO}$ accounting in some part for the underestimate in COfire.

These assumptions are also supported by comparison to the surface observations. Compared to the reference simulation, SENS_fire shows a small increase in the comparison to sites in Southern CA $(20 \pm 113 \mathrm{ppbV})$, but a clearly improved bias for Northern CA sites $(-103 \pm 97 \mathrm{ppbV})$. SENS_anthro, in contrast, clearly overestimates the CO mixing ratios in Southern CA $(224 \pm 120 \mathrm{ppbV})$ while at the same time showing a reduced bias in Northern CA $(-64 \pm 90 \mathrm{ppbV})$. The comparison to MOPITT over CA yields overall similar results for the three simulations: a bias of $(-19 \pm 17) \times 10^{16} \mathrm{~cm}^{-2}(-8 \pm 7 \%)$ for the reference run and of $(-17 \pm 18) \times 10^{16} \mathrm{~cm}^{-2}(-7 \pm 7 \%)$ and $(-16 \pm 17)$ $\times 10^{16} \mathrm{~cm}^{-2}(-7 \pm 7 \%)$ for SENS_fire and SENS_anthro, respectively.

Table 2 compares the total $\mathrm{CO}$ and $\mathrm{CO}$ tracer average mixing ratios between the reference and the sensitivity simulations. Releasing the fire emissions at the surface increases COfire mixing ratios (and owing to the first-order linearity in $\mathrm{CO}$ chemistry also total $\mathrm{CO}$ mixing ratios) on average by $82 \mathrm{ppbV}$ at the surface and by $67 \mathrm{ppbV}$ throughout the PBL. The mean relative contributions for COfire increase from $18 \pm 22 \%$ to $24 \pm 26 \%$ at the surface and from $17 \pm 21 \%$ to $23 \pm 26 \%$ in the PBL. We also estimate a small increase in the FT $(+7 \mathrm{ppbV}$ or a change in the relative contribution from $11 \pm 13 \%$ to $12 \pm 16 \%$ ). The main part of this FT increase might be explained by an increased residence time of $\mathrm{CO}$ in the domain in SENS_fire. When emissions are directly placed at higher altitudes, where the winds are more efficient in transporting them over large distances, they will move outside of the modeling domain faster compared to when they are released at the surface, where they first have to be lofted to higher altitudes before being transported by large-scale winds.

Changing the anthropogenic emissions (SENS_anthro) increases the average $\mathrm{CO}$ mixing ratio by $26 \mathrm{ppbV}$ at the surface, by $23 \mathrm{ppbV}$ in the PBL and by $3 \mathrm{ppbV}$ in the FT. The average relative contribution of COanthro increases by about $4 \%$ at the surface and the PBL and by about $2 \%$ in the FT. The tail of the COanthro distribution shows a clear increase with $10 \%$ of the surface data greater than $200 \mathrm{ppbV}$ in SENS_anthro compared to $131 \mathrm{ppbV}$ in the reference simulation. 


\section{Summary}

We use the regional Weather Research and Forecasting Model with Chemistry (WRF-Chem V3.2) and the global Model for OZone and Related Chemical Tracers (MOZART4) to examine CO contributions over California (CA) during the ARCTAS-CARB mission. We introduce model tracers into both models for tagging $\mathrm{CO}$ concentrations originating from individual sources. To our knowledge this is the first time that the concept of $\mathrm{CO}$ tracers, which is commonly used in global models, has been applied in a regional model.

The CO budget over CA for the time period 20 June- 15 July 2008 is estimated from the analysis of CO tracer fields in the regional model simulations in combination with global model results, the latter providing the lateral boundary conditions to WRF-Chem. CO tracers in the regional model include tracers for anthropogenic and fire emissions and photochemical $\mathrm{CO}$ production from within the regional domain, as well as $\mathrm{CO}$ transported into the regional domain from the lateral boundaries. $\mathrm{CO}$ tracers from the global model are used to further split the $\mathrm{CO}$ inflow tracer into $\mathrm{CO}$ originating from direct emissions in Asia, the contiguous US, Central America, and Europe and Africa.

We use aircraft measurements conducted during the ARCTAS-CARB mission, satellite retrievals from MOPITT and ground-based observations at monitoring stations to evaluate the model's ability to capture the actual CO distribution and variability. By combining these different types of data sets in the evaluation and including information from the model tracers in the interpretation of the results, we conclude that the model overall predicts the observed CO fields well, but points towards an underestimate of $\mathrm{CO}$ from the fires in Northern California, which had a strong influence during the study period, and towards a smaller overestimate of $\mathrm{CO}$ from pollution inflow and local anthropogenic sources.

The largest single source term to surface $\mathrm{CO}$ over $\mathrm{CA}$ is due to pollution inflow with a mean absolute mixing ratio of $99 \pm 11 \mathrm{ppbV} ; 26 \pm 7 \mathrm{ppbV}$ of this is attributed to direct emissions from Asia. Large influence from inflow is found in Northern CA and in the Sacramento Valley. The analysis of the Asian CO inflow tracer shows that the contributions from inflow in the Sacramento Valley are due to a combination of transport of surface air entering at the Carquinez Strait and downward transport of inflow bringing air masses below about $2-3 \mathrm{~km}$ to the surface as was also suggested by Parrish et al. (2010). A comparison between tracers in the global and the regional model shows that MOZART-4 statistically provides a good representation of the influence of long-range transport of $\mathrm{CO}$ on local air quality.

Anthropogenic emissions contribute on average $61 \pm 95 \mathrm{ppbV}$ to surface $\mathrm{CO}$ over $\mathrm{CA}$, which is smaller than the average contributions from COfire $(84 \pm 294 \mathrm{ppbV})$ reflecting the large effect of the intense fire season in CA in early summer 2008 on the atmospheric composition. In relative terms, $\mathrm{CO}$ inflow accounts for $53 \pm 21 \%$ of the surface $\mathrm{CO}$ and about $10 \%$ of the time more than $80 \%$ of the surface $\mathrm{CO}$ over CA is due to inflow. The average relative contributions of local anthropogenic and fire emissions are $22 \pm 18 \%$ and $18 \pm 22 \%$, respectively, and there is a $10 \%$ occurrence that at least half of the surface $\mathrm{CO}$ over CA is due to either of these sources. Photochemical $\mathrm{CO}$ production within the domain accounts for $8 \pm 4 \%$ of the surface $\mathrm{CO}$. In contrast, in the free troposphere (from the top of the boundary layer to $6 \mathrm{~km}$ ), the relative contributions for $\mathrm{CO}$ from inflow increases to $78 \pm 16 \%$, while the contribution of sources within the domain decreases: $6 \pm 5 \%$ for $\mathrm{CO}$ from local anthropogenic sources, $11 \pm 13 \%$ for $\mathrm{CO}$ from fires and $6 \pm 4 \%$ from photochemical production within the domain.

Sensitivity simulations demonstrate the importance of carefully characterizing not only the magnitude of emission sources, but also the nature of the source. In one sensitivity simulation, where the fire emissions are released at the lowest model level rather than being treated in a plume rise module, the average $\mathrm{CO}$ surface mixing ratio over $\mathrm{CA}$ increased from $260 \mathrm{ppbV}$ to $343 \mathrm{ppbV}$. A second sensitivity simulation demonstrates the importance of applying year-specific anthropogenic emissions. When the emissions were changed from the year specific inventory developed by CARB to the US EPA NEI inventory for 2005 the average surface CO mixing over CA changed from $260 \mathrm{ppbV}$ to $286 \mathrm{ppbV}$.

The results of this study demonstrate a strong contribution of many different types of emission sources on surface air quality over $\mathrm{CA}$ and the large variability on temporal and spatial scales associated with each of the source terms. We further demonstrate the importance of considering pollution from within the region as well as pollution coming from outside sources in analyzing California's air quality.

Acknowledgements. The authors like to acknowledge Stu McKeen (NOAA ESRL) for support in using the EPA-NEI emissions inventory. We further acknowledge Simone Tilmes and Merritt Deeter for providing valuable input to the manuscript and the two anonymous reviewers for their constructive comments. Acetonitrile measurements were supported by the Austrian Research Promotion Agency (FFG-ALR) and the Tiroler Zukunftstiftung and carried out with the help/support of T. Mikoviny, M. Graus, A. Hansel and T. D. Maerk. The research was supported by NASA grants NNX10AH45G, NNX08AD22G and NNX07AL57G. NCAR is operated by the University Corporation of Atmospheric Research under sponsorship of the National Science Foundation

Edited by: A. Stohl 


\section{References}

Akagi, S. K., Yokelson, R. J., Wiedinmyer, C., Alvarado, M. J., Reid, J. S., Karl, T., Crounse, J. D., and Wennberg, P. O.: Emission factors for open and domestic biomass burning for use in atmospheric models, Atmos. Chem. Phys., 11, 4039-4072, doi:10.5194/acp-11-4039-2011, 2011.

Arellano, A. F., Kasibhatla, P. S., Giglio L., van der Werf, G. R., and Randerson, J. T.: Top-down estimates of global CO sources using MOPITT measurements, Geophys. Res. Lett., 31, L01104, doi:10.1029/2003GL018609, 2004.

Arellano, A. F., Kasibhatla, P. S., Giglio, L., van der Werf, G. R., Randerson, J. T., and Collatz, G. J.: Time-dependent inversion estimates of global biomass-burning $\mathrm{CO}$ emissions using Measurement of Pollution in the Troposphere (MOPITT) measurements, J. Geophys. Res., 111, D09303, doi:10.1029/2005JD006613, 2006.

Bey, I., Jacob, D. J., Yantosca, R. M., Logan, J. A., Field, B. D. , Fiore, A. M., Li, Q. , Liu, H. Y., Mickley, L. J., and Schultz, M. G.: Global modeling of tropospheric chemistry with assimilated meteorology: Model description and evaluation, J. Geophys. Res., 106, 23073-23095, 2001.

Bougeault, P. and Lacarrere, P.: Parameterisation of OrographyInduced Turbulence in a Mesobeta-Scale Model, Mon. Weather Rev., 117, 1872-1890, 1989.

Chin, M., Ginoux, P., Kinne, S. Holben, B. N., Duncan, B. N, Martin, R. V., Logan, J. A, Higurashi, J., and Nakajima, T.: Tropospheric aerosol optical thickness from the GOCART model and comparisons with satellite and sunphotometer measurements, J. Atmos. Sci. 59, 461-483, 2002.

Deeter, M. N., Edwards, D. P., Gille, J. C., Emmons, L. K., Francis, G., Ho, S.-P., Mao, D., Masters, D., Worden, H., Drummond, J. R., and Novelli, P. C.: The MOPITT version 4 CO product: Algorithm enhancements, validation, and long-term stability, J. Geophys. Res., 115, D07306, doi:10.1029/2009JD013005, 2010.

Diskin, G. S., Podolske, J. R., Sachse, G. W., and Slate, T. A.: Open-Path Airborne Tunable 15 Diode Laser Hygrometer, in Diode Lasers and Applications in: Atmospheric Sensing, SPIE Proceedings 4817, edited by: Fried, A., 196-204, doi:10.1117/12.453736, 2002.

Duncan, B. N., Logan, J. A., Bey, I., Megretskaia, I. A., Yantosca, R. M., Novelli, P. C., Jones, N. B., and Rinsland, C. P.: Global budget of CO, 1988-1997: Source estimates and validation with a global model, J. Geophys. Res., 112, D22301, doi:10.1029/2007JD008459, 2007.

Ek, M. B., Mitchell, K. E. Lin, Y., Rogers, E., Grunmann, P., Koren, V., Gayno, G., and Tarpley, J. D.: Implementation of Noah land surface model advances in the National Centers for Environmental Prediction operational mesoscale Eta model, J. Geophys. Res., 108(D22), 8851, doi:10.1029/2002JD003296, 2003.

Emmons, L. K., Walters, S., Hess, P. G., Lamarque, J.-F., Pfister, G. G., Fillmore, D., Granier, C., Guenther, A., Kinnison, D., Laepple, T., Orlando, J., Tie, X., Tyndall, G., Wiedinmyer, C., Baughcum, S. L., and Kloster, S.: Description and evaluation of the Model for Ozone and Related chemical Tracers, version 4 (MOZART-4), Geosci. Model Dev., 3, 43-67, doi:10.5194/gmd3-43-2010, 2010.

Fiore, A. M., Dentener, F. J., Wild, O., Cuvelier, C., Schultz, M. G., Hess, P., Textor, C., Schulz, M., Doherty, R. M., Horowitz, L. W., MacKenzie, I. A., Sanderson, M. G., Shindell, D. T., Steven- son, D. S., Szopa, S., Van Dingenen, R., Zeng, G., Atherton, C., Bergmann, D., Bey, I., Carmichael, G., Collins, W. J., Duncan, B. N., Faluvegi, G., Folberth, G., Gauss, M., Gong, S., Hauglustaine, D., Holloway, T., Isaksen, I. S. A., Jacob, D. J., Jonson, J. E., Kaminski, J. W., Keating, T. J., Lupu, A., Marmer, E., Montanaro, V., Park, R. J., Pitari, G., Pringle, K. J., Pyle, J. A., Schroeder, S., Vivanco, M. G., Wind, P., Wojcik, G., Wu, S., and Zuber, A.: Multimodel estimates of intercontinental source- receptor relationships for ozone pollution, J. Geophys. Res., 114, D04301, doi:10.1029/2008JD010816, 2009.

Freitas, S. R., Longo, K. M., Chatfield, R., Latham, D., Silva Dias, M. A. F., Andreae, M. O., Prins, E., Santos, J. C., Gielow, R., and Carvalho Jr., J. A.: Including the sub-grid scale plume rise of vegetation fires in low resolution atmospheric transport models, Atmos. Chem. Phys., 7, 3385-3398, doi:10.5194/acp-7-33852007, 2007.

Friedl, M. A., Sulla-Menashe, D., Tan, B., Schneider, A., Ramankutty, N., Sibley, A., and Huang, X.: MODIS collection 5 global land cover: algorithm refinements and characterization of new datasets, Remote Sens. Environ., 114(1), 168-182, 2010.

Fritz, S., Bartholomé, E., Belward, A., Hartley, A., Stibig H. J., Eva, H., Mayaux, P., Bartalev, S., Latifovic, R., Kolmert, S., Roy, P., Agrawal, S., Bingfang, W., Wenting, X., Ledwith, M., Pekel, F.J., Giri, C., Mücher, S., de Badts, E., Tateishi, R., Champeaux, J.-L., and Defourny, P.: Harmonization, mosaicing, and production of the Global Land Cover 2000 database, Ispra, Italy, Joint Research Center (JRC), 2003.

Granier, C., Mueller, J. F., Petron, G., and Brasseur, G.: A three dimensional study of the global CO budget, Glob. Change Sci., 1, 255-261, 1999.

Granier, C., Petron, G., Muller, J.-F., and Brasseur, G.: The impact of natural and anthropogenic hydrocarbons on the tropospheric budget of carbon monoxide, Atmos. Environ., 34, 5255-5270, doi:10.1016/S1352-2310(00)00299-5, 2000.

Grell, G. A., Peckham, S. E., Schmitz R., McKeen, S. A., Frost, G., Skamarock, W. C., and Eder, B.: Fully coupled online chemistry within the WRF model, Atmos. Environ., 39, 6957-6975, 2005.

Guenther, A., Karl, T., Harley, P., Wiedinmyer, C., Palmer, P. I., and Geron, C.: Estimates of global terrestrial isoprene emissions using MEGAN (Model of Emissions of Gases and Aerosols from Nature), Atmos. Chem. Phys., 6, 3181-3210, doi:10.5194/acp-63181-2006, 2006.

Heald, C. L., Jacob, D. J, Jones, D. B. A., Palmer, P. I., Logan, J. A., Streets, D. G., Sachse, G. W., Gille, J. C., Hoffman, R. N., and Nehrkorn, T.: Comparative inverse analysis of satellite (MOPITT) and aircraft (TRACE-P) observations to estimate Asian sources of carbon monoxide, J. Geophys. Res., 109, D15S04, doi:10.1029/2004JD005185, 2004.

Holzer, M. and Hall, T. M.: Low-level transpacific transport, J. Geophys. Res., 112, D09103, doi:10.1029/2006JD007828, 2007.

Horowitz, L. W., Walters, S., and Mauzarall, D. L.: A global simulation of tropospheric ozone and related tracers: Description and evaluation of MOZART, version 2, J. Geophys. Res., 108(D24), 4784, doi:10.1029/2002JD002853, 2003.

Huang, M., Carmichael, G. R., Adhikary, B., Spak, S. N., Kulkarni, S., Cheng, Y. F., Wei, C., Tang, Y., Parrish, D. D., Oltmans, S. J., D’Allura, A., Kaduwela, A., Cai, C., Weinheimer, A. J., Wong, M., Pierce, R. B., Al-Saadi, J. A., Streets, D. G., and Zhang, Q.: Impacts of transported background ozone on California air qual- 
ity during the ARCTAS-CARB period - a multi-scale modeling study, Atmos. Chem. Phys., 10, 6947-6968, doi:10.5194/acp-106947-2010, 2010.

Jacob, D. J., Crawford, J. H., Maring, H., Clarke, A. D., Dibb, J. E., Emmons, L. K., Ferrare, R. A., Hostetler, C. A., Russell, P. B., Singh, H. B., Thompson, A. M., Shaw, G. E., McCauley, E., Pederson, J. R., and Fisher, J. A.: The Arctic Research of the Composition of the Troposphere from Aircraft and Satellites (ARCTAS) mission: design, execution, and first results, Atmos. Chem. Phys., 10, 5191-5212, doi:10.5194/acp-10-5191-2010, 2010.

Kopacz, M., Jacob, D. J., Fisher, J. A., Logan, J. A., Zhang, L., Megretskaia, I. A., Yantosca, R. M., Singh, K., Henze, D. K., Burrows, J. P., Buchwitz, M., Khlystova, I., McMillan, W. W., Gille, J. C., Edwards, D. P., Eldering, A., Thouret, V., and Nedelec, P.: Global estimates of CO sources with high resolution by adjoint inversion of multiple satellite datasets (MOPITT, AIRS, SCIAMACHY, TES), Atmos. Chem. Phys., 10, 855-876, doi:10.5194/acp-10-855-2010, 2010.

Li, Q., Jacob, D. J., Bey, I., Palmer, P. I., Duncan, B. N., Field, B. D., Martin, R. V., Fiore, A. M., Yantosca, R. M., Parrish, D. D., Sim- monds, P. G., and Oltmans, S. J.: Transatlantic transport of pollution and its effects on surface ozone in Europe and North America, J. Geophys. Res., 107(D13), 4166, doi:10.1029/2001JD001422, 2002.

Liang, Q., Jaegle, L., Jaffe, D. A., Weiss-Penzias, P., Heckman, A., and Snow, J. A.: Long-range transport of Asian pollutionto the northeast Pacific: Seasonal variations and transport pathways of carbon monoxide, J. Geophys. Res., 109, D23S07, doi:10.1029/2003JD004402, 2004.

Liu, J., Mauzerall, D. L., and Horowitz, L. W.: Source-receptor relationships between East Asian sulfur dioxide emissions and Northern Hemisphere sulfate concentrations, Atmos. Chem. Phys., 8, 3721-3733, doi:10.5194/acp-8-3721-2008, 2008.

Palmer, P. I., Jacob, D. J., Jones, D. B. A., Heald, C. L., Yantosca, R. M., Logan, J. A., Sachse, G. W., and Streets, D. G.: Inverting for emissions of carbon monoxide from Asia using aircraft observations over the western Pacific, J. Geophys. Res., 108(D21), 4180, doi:10.1029/2003JD003397, 2003.

Parrish, D. D., Aikin, K. C., Oltmans, S. J., Johnson, B. J., Ives, M., and Sweeny, C.: Impact of transported background ozone inflow on summertime air quality in a California ozone exceedance area, Atmos. Chem. Phys., 10, 10093-10109, doi:10.5194/acp10-10093-2010, 2010.

Pétron, G., Granier, C. Khattatov, B. Yudin, V. Lamarque, J.-F., Emmons, L., Gille, J., and Edwards, D. P.: Monthly CO surface sources inventory based on the 20002001 MOPITT satellite data, Geophys. Res. Lett., 31, L21107, doi:10.1029/2004GL020560, 2004.

Pfister, G., Petron, G., Emmons, L. K., Gille, J. C., Edwards, D. P., Lamarque, J.-F., Attie, J.-L., Granier, C., and Novelli, P. C.: Evaluation of CO simulations and the analysis of the CO budget for Europe, J. Geophys. Res., 109, D19304, doi:10.1029/2004JD004691, 2004.

Pfister, G., Hess, P. G., Emmons, L. K., Lamarque, J.-F., Wiedinmyer, C., Edwards, D. P., Petron, G., Gille, J. C., and Sachse, G. W.: Constraints on Emissions for the Alaskan Wildfires 2004 using Data Assimilation and Inverse Modeling of MOPITT CO, Geophys. Res. Lett., 32(11), L11809, doi:10.1029/2005GL022995, 2005.
Pfister, G. G., Emmons, L. K., Edwards, D. P., Arellano, A., G Sachse, and Campos, T.: Variability of springtime transpacific pollution transport during 2000-2006: the INTEX-B mission in the context of previous years, Atmos. Chem. Phys., 10, 13451359, doi:10.5194/acp-10-1345-2010, 2010.

Pfister, G. G., Parrish, D. D., Worden, H., Emmons, L. K., Edwards, D. P., Wiedinmyer, C., Diskin, G. S., Huey, G., Oltmans, S. J., Thouret, V., Weinheimer, A., and Wisthaler, A.: Characterizing summertime chemical boundary conditions for airmasses entering the US West Coast, Atmos. Chem. Phys., 11, 1769-1790, doi:10.5194/acp-11-1769-2011, 2011.

Provencal, R., Gupta, M., Owano, T. G, Baer, D. S., Ricci, K. N., O'Keefe, A., and Podolske, J. R.: Cavity-enhanced quantumcascade laser-based instrument for carbon monoxide measurements, Appl. Opt., 44, 6712-6717, 2005.

Reidmiller, D. R., Fiore, A. M., Jaffe, D. A., Bergmann, D., Cuvelier, C., Dentener, F. J., Duncan, B. N., Folberth, G., Gauss, M., Gong, S., Hess, P., Jonson, J. E., Keating, T., Lupu, A., Marmer, E., Park, R., Schultz, M. G., Shindell, D. T., Szopa, S., Vivanco, M. G., Wild, O., and Zuber, A.: The influence of foreign vs. North American emissions on surface ozone in the US, Atmos. Chem. Phys., 9, 5027-5042, doi:10.5194/acp-9-5027-2009, 2009.

Sachse, G. W., Hill, G. F., Wade, L. O., and Perry, M. G.: Fast response, high precision carbon monoxide sensor using a tunable diode laser absorption technique, J. Geophys. Res., 92, 20712081, 1987.

Staudt, A. C., Jacob, D. J., Logan, J. A., Bachiochi, D., Krishnamurti, T. N., and Sachse, G. W.: Continental sources, transoceanic transport, and interhemispheric exchange of carbon monoxide over the Pacific, J. Geophys. Res., 106(D23), 3257132590, 2001.

Stohl, A., Eckhardt, S., Forster, C., James, P., and Spichtinger, N.: On the pathways and timescales of intercontinental air pollution transport, J. Geophys. Res., 107(D23), 4684, doi:10.1029/2001JD001396, 2002.

Warneck, P.: Chemistry of the Natural Atmosphere, 927 pp., Academic, San Diego, CA, 2000.

Warneke, C., de Gouw, J. A., Stohl, A., Cooper, O. R., Goldan, P. D., Kuster, W. C., Holloway, J. S., Williams, E. J., Lerner, B. M., McKeen, S. A., Trainer, M., Fehsenfeld, F. C., Atlas, E. L., Donnelly, S. G., Strout, V., Lueb, A., and Kato, S.: Biomass burning and anthropogenic sources of CO over New England in the summer 2004, J. Geophys. Res., 111, D23S15, doi:10.1029/2005JD006878, 2006.

Wiedinmyer, C., Quayle, B., Geron, C., Belote, A., McKenzie, D., Zhang, X., O’Neill, S., and Wynne, K. K.: Estimating emissions from fires in North America for air quality monitoring, Atmos. Environ., 40, 3419-3432, 2006.

Wiedinmyer, C., Akagi, S. K., Yokelson, R. J., Emmons, L. K., AlSaadi, J. A., Orlando, J. J., and Soja, A. J.: The Fire INventory from NCAR (FINN): a high resolution global model to estimate the emissions from open burning, Geosci. Model Dev., 4, 625641, doi:10.5194/gmd-4-625-2011, 2011.

Yashiro, H., Sugawara, S., Sudo, K., Aoki, S., and Nakazawa, T.: Temporal and spatial variations of carbon monoxide over the western part of the Pacific Ocean, J. Geophys. Res., 114, D08305, doi:10.1029/2008jd010876, 2009. 